Issue no. $25 / 2018$

\title{
FORESIGHT AND THE MACROECONOMIC IMPACT OF FISCAL POLICY: EVIDENCE FOR FRANCE, GERMANY AND ITALY ${ }^{3}$
}

\author{
Lilia CAVALLARI ${ }^{4}$ \\ Simone ROMANO5
}

DOI:10.24193/OJMNE.2018.25.02

\begin{abstract}
This contribution provides evidence in support of the hypothesis that fiscal policy is largely anticipated and its effects depend on expectations. Based on a 2-country Bayesian VAR model between major European economies, we found that an unanticipated fiscal stimulus leads to expectations of strong deficit reversals. This in turn depresses domestic and foreign activity. Foresight shocks, on the contrary, have positive effects on domestic activity. Differences in the responses to surprise and foresight shocks reflect the role of expectations. The evidence in our study is consistent with a regime where deficit reversals are mainly based on taxation alone.
\end{abstract}

Keywords: Fiscal policy, VAR model, Fiscal spillovers, Fiscal multiplier

\section{Introduction}

Evidence about the macroeconomic impact of fiscal policy is abundant yet controversial. Estimates of the government spending multiplier range from 0.5 to 2.5 in the United States depending on the estimation approach. ${ }^{6}$ Moreover, they vary considerably over time and across countries. It is by now well-understood that fiscal multipliers are higher in recessions (Auerbach and Gorodnichenko (2012)) and depend on such a large set of circumstances, including the exchange rate regime, trade openness, financial development, financial health and the state of public finances, that the notion of multiplier itself is put into

\footnotetext{
${ }^{3}$ An extended version of this paper has been published in Economic Modelling vol.60, 81-97, 2017 under the title "Fiscal policy in Europe: the importance of making it predictable".

${ }^{4}$ University of Rome III, Department of Political Science. Email: lilia.cavallari@uniroma3.it

${ }^{5}$ University of Rome III, Department of Political Science. Email: simone.romano@ uniroma3.it

${ }^{6}$ The Congressional Budget Office (2012) provides a detailed survey. See also Reichling and Wahlen (2012) and Ramey (2011b).
} 
Issue no. $25 / 2018$

question. ${ }^{7}$ Results are mixed when it comes to evaluating the international effects of fiscal policy. In the euro area, Caporale and Girardi (2013) document a significant impact of fiscal imbalances in a given EMU country on the borrowing costs faced by its EMU partners. Higher interest rates crowd-out private expenditure and reduce the efficacy of debt-financed fiscal expansions. Canova et al. (2013), on the contrary, document limited and even perverse effects on long-term yields. In their panel, most of the action comes through the trade channel: a fiscal expansion in one country leads to higher imports and has positive output spillovers in partner economies ${ }^{8}$.

On the methodological ground, the fact that fiscal policy can be anticipated to a large extent poses a non-trivial identification problem. Fiscal variables are the result of a complex decision process, entailing long lags between the moment when the decision is taken and when it is effectively implemented. In the absence of a proper account of predictability, these variables may not convey sufficient information for identifying structural shocks, a problem known as non-fundamentalness. Clearly, estimated responses may be misleading and very far from the true ones whenever fiscal shocks are not properly identified. In the words of Ramey (2011a), identifying fiscal shocks is all in the timing.

In this paper, we revisit the effects of fiscal policy on both domestic and foreign activity at the light of fiscal foresight. For this purpose, we use the official forecasts of the European Commission to identify surprise and foresight shocks. The former are unpredictable changes in the policy that is actually in place and capture innovations within a given policy regime. The latter are unpredictable changes in policy forecasts and reflect revision of expectations about future policy actions, namely regime shifts. The analysis draws on twocountry VAR models between major European economies that include measures of both realized and expected policy together with country-specific GDP, bilateral exports and long-

\footnotetext{
7 Empirical explorations into the determinants of government spending multipliers include, among others, Auerbach and Gorodnichenko (2013), Corsetti et al. (2012), Ilzetzki et al. (2013), Christiano et al. (2011), Caldara and Kemps (2012), Erceg and Linde (2012), Leeper et al. (2011), and Woodford (2009). See also Caggiano et al. (2014), Guajardo et al. (2011).

${ }^{8}$ Previous studies documenting positive output spillovers from fiscal expansion in the EMU include, among others, Beetsma and Giuliodori (2004) and Beetsma et al. (2006).
} 
Issue no. $25 / 2018$

term interest rate differentials. The fiscal stance is captured by the government balance (ratio to GDP) from the European Commission Forecasts. Data refer to Italy, France and Germany over the period 1971-2011. Fiscal shocks are identified as in Forni and Gambetti (2014) through a recursive ordering in which the realized policy does not react within the year to innovations in any other variable in the system. The expected policy, on the contrary, is allowed to react to innovations in the realized policy, reflecting the revision of expectations upon arrival of news.

We provide evidence in support of the hypothesis that fiscal policy is largely anticipated and its effects depend on expectations about future policy actions. We first document the forecasting accuracy of the European Commission Forecasts and show that they help address the problem of non-fundamentalness in the identification of fiscal shocks. Then, we estimate the effects of surprise and foresight shocks. An unanticipated fiscal stimulus (the surprise shock) is found to generate expectations of strong deficit reversals over the subsequent two to three years and to depress domestic and foreign activity over the same horizon. This is consistent with a regime where deficit reversals are mainly based on taxation alone. A different picture emerges when the fiscal stimulus is engineered through a change in expectations. An anticipated fiscal expansion (the foresight shock) has positive effects on domestic activity.

The paper is organized as follows. Section 2 verifies the forecast accuracy of the European Commission Forecasts and assesses their implications for the identification of fiscal shocks. Section 3 presents the econometric approach and section 4 discusses the results. Section 5 concludes.

\section{Fiscal foresight}

It is amply recognized that fiscal policy can be anticipated to a large extent. Yet, empirical evidence documenting fiscal foresight with time series data is scarce. Most contributions focus on government spending in the United States, including Ramey (2011a), Perotti (2011) and Forni and Gambetti (2014) among others. Using the Survey of Professional Forecasters, these studies suggest that the forecasts of government spending provide useful information about the prospective developments not only of government 
spending itself but also of private consumption and output growth. ${ }^{9}$ Ignoring this information can cause serious estimation bias.

In this section, we will assess the extent to which publicly available forecasts of the government balance in Italy, France and Germany provide information about future policy developments and their role for the identification of structural shocks. For this purpose, we use the European Commission Forecasts, ECF henceforth. The ECF report, for each year over the period 1971-2011, the forecast of the government balance (ratio to GDP), $d_{t}$, made at the beginning of the period for the current and the subsequent period, $f_{t}\left(d_{t}\right)$ and $f_{t}\left(d_{t+1}\right)$, respectively. Forecasts are released in the spring and autumn of each year. From the original data, we derive the cumulated forecast:

$F t=f t(d t)+f t(d t+1)$ the forecast error:

$F e_{t}=f_{t}\left(d_{t}\right)-d_{t}$

and the forecast news:

$$
F n t=f t(d t)-f t-1(d t)
$$

Each of the indicators above reflects a different aspect of the forecasting process. The cumulated forecast captures the expected change in the government balance between $\mathrm{t}$ and $\mathrm{t}+1$. Using information over a two-year horizon, it may perform better in terms of accuracy compared to the simple forecasts $f_{t}\left(d_{t}\right)$ and $f_{t}\left(d_{t+1}\right)$. The forecast error provides information about the accuracy of the EC forecasts. The forecast news conveys the new information that becomes available at each time t.

As a preliminary step, we evaluate the forecasting accuracy of the European Commission Forecasts as compared to standard time series models. The target is the realized government balance-to-GDP ratio (see below for a complete description of the data) over the period 1971-2011. The time series models we use are univariate autoregressive models with

\footnotetext{
${ }^{9}$ In Europe, see Gonzales et al. (2012).
} 
Issue no. $25 / 2018$

maximum order 2. The initial sample date is 1971 and the parameters are estimated with a rolling windows of 16 years. Forecast accuracy is measured by the mean square forecast error, MSFE, normalized by the variance of the target. The MSFE is the fraction of unpredictable variance: the lower the MSFE the higher the degree of foresight. Results are reported in Table 1.

The forecasts of the European Commission appear more accurate compared to the best performing autoregressive model. The MSFE of the ECF is lower than in any time series model and the difference is significant at the 5 percent level according to the DieboldMariano test (Diebold and Mariano (1995)). These findings are in line with previous studies documenting the forecast accuracy of the ECF (Gonzales et al. (2012)). They suggest that the forecasts of the European Commission convey useful information for predicting the government balance.

Table 1: Forecast Accuracy

\section{GERMANY}

ARMA $(1,1)$

$\operatorname{ARMA}(1,2)$

ARMA $(2,1)$

$\operatorname{ARMA}(2,2)$

EU Commission Forecast (1996-2011)

FRANCE

ARMA $(1,1)$

$\operatorname{ARMA}(1,2)$

$\operatorname{ARMA}(2,1)$

ARMA $(2,2)$

EU Commission Forecast (1996-2011)

ITALY

$\operatorname{ARMA}(1,1)$

$\begin{array}{lll}\text { Log-likelihood } & \text { MSE } & \text { MSFE } \\ -42,96501 & 1,95490 & 4,09730 \\ -43,42423 & 1,96620 & 1,98760 \\ -42,37214 & 1,85030 & 3,24460 \\ -42,36907 & 1,85110 & 3,27830 \\ & & 1,021875\end{array}$

Log-likelihood MSE MSFE

$-50,69220$

$3,77270 \quad 3,63410$

$-47,48858$

$3,24900 \quad 9,10010$

$-50,48945$

$3,70650 \quad 3,59000$

$-47,15581$

$3,23110 \quad 8,23130$

0,29938

Log-likelihood MSE MSFE

$\begin{array}{lll}-38,31310 & 1,31620 & 1,48700\end{array}$ 
Issue no. $25 / 2018$

ARMA $(1,2)$

$\begin{array}{lll}-38,29995 & 1,31620 & 1,49400 \\ -38,28995 & 1,31560 & 1,50030 \\ -38,28959 & 1,31540 & 1,49940 \\ & & 0,33875\end{array}$

ARMA $(2,1)$

ARMA $(2,2)$

EU Commission Forecast (1996-2011)

0,33875

The table reports the log-likelihood and the mean square error, MSE, of the regression in row together with the mean square forecast error, MSFE, of the deficit forecast from ARMA models and from the European Commission Forecasts. Data cover the period 19962011.

It is well-known that omitting information can cause serious estimation bias (Forni and Reichlin (1998)). In VAR models, overlooking the effect of anticipated policies may lead to a non-fundamental structural MA representation (Leeper et al. (2013)). Because fiscal variables react with a delay to innovations in any other variable in the system, they may not provide sufficient information to identify structural shocks. As a consequence, the VAR results can be misleading and the estimated responses very far from the true ones (Ramey (2011a)). A similar problem occurs in monetary models that do not consider variables in the information set of central banks. Energy prices, for instance, provide useful information about future inflation and omitting them can cause a price puzzle, i.e. a positive response of inflation to an increase in the policy rate.

We verify the existence of a fundamental MA representation using the orthogonality test proposed by Forni and Gambetti (2014). The test is based on a simple rational: fundamentalness requires that any linear combination of the estimated residuals is not correlated with the past realizations of available information. If the condition is not satisfied, a fundamental MA representation does not exist and the VAR model is misspecified, in the sense that it does not include sufficient information to identify structural shocks. The testing procedure is the following: first, estimate a VAR model and identify the shocks of interest; second, regress these shocks on the past values of variables that reflect available information and perform an F-test for the significance of the regression. Our regressors include the EC forecasts and the indicators (1), (2) and (3).

As it will be clear soon, we focus on deficit shocks (the econometric model is described below). These are identified as the first shock in a Cholesky decomposition of the 
Issue no. $25 / 2018$

VAR(2) including, in this order, the government deficit (ratio to GDP) and GDP of each country, taken one at a time, together with GDP, net bilateral exports (ratio to GDP) and long term interest rate differentials for each partner economy considered in turn. The model is estimated separately for each country pair over the period $1971-2011 .{ }^{10}$ The estimated deficit shocks are then used to perform the orthogonality test. They are regressed on five sets of regressors, including the series reported by the ECF and the indicators (1), (2) and (3), considered one at a time. The sixth regression contains all of these series together. The first five regressions contain up to 2 lags of the regressors so as to capture information far in the past. For efficiency reasons, the sixth regression contains only contemporaneous regressors. Results are shown in Table 2. The table reports the p-values of the F-test for the six sets of regressors, in rows, and for all country pairs, in columns. Orthogonality is clearly rejected in the regressions using all available forecasts, All, and in the regressions using forecast errors, $F E_{t}$. It is not rejected in most of the remaining cases. We conclude that non-fundamentalness cannot be excluded in our VAR model.

\section{The econometric approach}

In this section we analyze the macroeconomic effects of fiscal stimulus, as measured by an increase in the government deficit-to-GDP ratio, in France, Germany, and Italy. Our analysis is focused on unexpected variations in government deficits, i.e. surprise shocks, as compared to unexpected variations in deficit forecasts, i.e. foresight shocks.

Table 2: Fundamentalness test

$\begin{array}{lll}\text { Regressors } & \text { Germany - Italy } & \text { Germany - France } \\ \text { Nowcast } & 0,004 & 0,007 \\ \text { 1 Year Ahead } & 0,445 & 0,586 \\ \text { Cumulated (1) } & 0,064 & 0,096 \\ \text { Forecast Error (2) } & 0,019 & 0\end{array}$

\footnotetext{
${ }^{10}$ The impulse responses together with $68 \%$ and $90 \%$ confidence intervals are available upon request.
} 
Issue no. $25 / 2018$

$\begin{array}{lll}\text { News (3) } & 0,242 & 0,147 \\ \text { ALL } & 0 & 0 \\ \text { Regressors } & \text { Italy - Germany } & \text { Italy - France } \\ \text { Nowcast } & 0,418 & 0,276 \\ 1 \text { Year Ahead } & 0,701 & 0,862 \\ \text { Cumulated (1) } & 0,458 & 0,513 \\ \text { Forecast Error (2) } & 0 & 0 \\ \text { News (3) } & 0,48 & 0,374 \\ \text { ALL } & 0 & 0 \\ \text { Regressors } & \text { France - Germany } & \text { France - Italy } \\ \text { Nowcast } & 0,273 & 0,145 \\ \text { 1 Year Ahead } & 0,883 & 0,946 \\ \text { Cumulated (1) } & 0,848 & 0,684 \\ \text { Forecast Error (2) } & 0 & 0 \\ \text { News (3) } & 0,556 & 0,345 \\ \text { ALL } & 0 & 0\end{array}$

The table reports the p-values of the F-test for each set of regressors (in rows) and for different samples (in columns). The first five regressions contain up to two lags for each regressor while the sixth regression contains one lag for each regressor.

We consider surprise and foresight shocks in each of these countries in turn and estimate their effects on domestic and foreign activity as well as on interest rate differentials and bilateral exports.

Our main interest relates to the role of forecasts for the domestic and cross-border transmission of shocks: how are domestic and foreign output affected by a fiscal stimulus that may be reversed in the future? How are they affected by a change in expectations about future policy actions? How effective is a fiscal stimulus that will take place in the future?

The notion that the effects of fiscal stimulus depend on expectations about future policy actions is well-known at least since Barro (1974). He showed that for a given pattern of government expenditure, how that spending is financed has no consequences for aggregate 
Issue no. $25 / 2018$

demand. The argument is based on the fact that agents smooth consumption over their whole lifetime. Consider, for instance, a debt-financed increase in government spending today that will be completely o set by higher (future) taxation alone. The prospective of lower disposable income in the future provides an incentive for agents to contract their current expenditures, so as to smooth consumption over time. As a consequence, the real interest rate raises and expectations of higher taxes completely crowd-out private expenditure. In a regime where both government spending and taxes automatically adjust so as to consolidate public debt over time, Corsetti et al. (2011) show that fiscal stimulus might in principle crowd-in private expenditure. In such a regime, the initial increase in the government deficit triggers a subsequent reversal of spending cuts or tax hikes that leads the deficit below trend for a while. Interest rates may even fall, boosting private spending. The extent to which expectations about future policy actions affect the impact of fiscal stimulus is ultimately an empirical matter. In what follows, we propose a methodology to shed some light on the question.

\subsection{Data}

We use annual data for Germany, Italy and France over the period 1971-2011, where the frequency reflects availability of foresight data. Table 3 in Appendix A reports key information on the original series and data transformations.

Macroeconomic data are from the OECD StatExtract database. They comprise GDP measured at constant prices with base year 2010 - and the consumer price index, CPI. Bilateral imports and exports - denominated in US dollars at current prices - are from the UN Comtrade database. They are expressed in euros using the euro-dollar exchange rate from Eurostat and deflated with the CPI. Finally, the series of the government balance (ratio to GDP) - both realizations and forecasts - are from the European Commission. We have multiplied the original series by -1 so that positive values represent government deficits.

\subsection{The model}

Consider the VAR model given by:

$$
Y_{t}=B(L) Y_{t-1}+\epsilon_{t}
$$


where $Y_{t}$ is the $(n \times 1)$ vector of endogenous variables, $B(L)$ are $(n \times n)$ matrix polynomials in the lag operator and $t_{t}$ is the $(n \times 1)$ vector of errors in the system. The vector of endogenous comprises the government deficit (ratio to GDP), one of the forecast indicators (1), (2) and (3) and real GDP for each country $i=1, . ., 3$ considered in turn together with real GDP, net bilateral exports (ratio to GDP), $n x$, and the interest rate differential on 10-year government bonds, spread, for each country $j=1, . ., 3$, with $j 6=i$ considered in turn:

$$
Y t=\left[\begin{array}{lllll}
\text { di,t } & \text { Fi,t/Fei,t/Fni,t } \quad G D P i, t \quad G D P j, t & n x j, t & \text { spreadj,t }
\end{array}\right]
$$

The model is estimated separately for each country pair. All variables except interest differentials are HP filtered with a smoothing parameter $\lambda=6.5$ as is usual in business cycle studies. ${ }^{11}$ Cyclical adjustment is amply used in fiscal studies (see van der Noord (2000) and In 't Veld et al. (2013)). Typically, the cyclical component of a fiscal variable is meant to capture discretionary policy, which is largely unpredictable, while the trend component reflects predictable movements due to the functioning of automatic stabilizers.

Given the scope of the study, which is focused on the macroeconomic impact of fiscal stimulus at home and abroad, we have included also variables that capture the main channels of international transmission. Net bilateral exports represent trade spillovers: a fiscal expansion in one country is expected to spread its effects abroad through an increase in imports from the trading partners, so that bilateral exports from country $j$ to country $i$ increase after a fiscal expansion in country $i$. Interest differentials capture spillovers through the financial channel. The effect of a fiscal expansion on the spread is a priori ambiguous. A fiscal expansion may induce an upward correction of the risk premium required on government bonds, especially in highly indebted countries. This implies an increase (decrease) in the spread of countries that are more (less) exposed to sovereign risk.

Identification of fiscal shocks is achieved by assuming a contemporaneous recursive ordering where exogenous variables are ordered as given in the definition of $Y_{t}$. Zero contemporaneous restrictions are popular in fiscal studies (see Fatas and Mihov (2001) and

\footnotetext{
${ }^{11}$ Using non-cyclically adjusted variables is inconsequential for the analysis. The impulse responses of noncyclically adjusted variables are available upon request.
} 
Issue no. $25 / 2018$

Blanchard and Perotti (2002)). They are based on the premise that fiscal policy involves a decision process characterized by long and variable lags between the time when a decision is made and when it is actually implemented. As a consequence, fiscal variables react with a lag of at least one period to innovations in any other variable in the system. Specifically, we assume that the government deficit does not react within the year to innovations in any other variable in the system. To identify foresight shocks, we assume further that innovations to deficits can have a contemporaneous impact on the foresight indicator while innovations to the foresight indicator have no impact on the deficit realized within the year. The assumption reflects the incentive to revise forecasts upon arrival of news about the realized deficit.

To gain further insight on our identification strategy, consider the Wold representation of the government deficit:

$$
d_{t}=\alpha(L) \varepsilon_{t}+\beta(L) \eta_{t}+\delta(L) \xi_{t}
$$

Where $\alpha(L)=\sum_{k=0}^{\infty} \alpha_{k} L^{k}, \beta(L)=\sum_{k=0}^{\infty} \beta_{k} L^{k}$, and $\delta(L)=\sum_{k=0}^{\infty} \delta_{k} L^{k}$ are impulse response functions in the lag operator $\mathrm{L}_{t}$ is the foresight shock, $\eta_{t}$ is the surprise shock and $\xi_{t}$ is a nonpolicy shock reflecting endogenous variations, for instance because of the functioning of automatic stabilizers. By definition of news, the deficit reacts with some delay s to $t$, implying $\alpha_{k}=0$ for $k<s$. The non-policy shock also affects the deficit with delay (as in Blanchard and Perotti (2002)). The surprise shock is, on the contrary, characterized by $\beta_{0} \neq 0$. In this setup, the surprise shock reflects unanticipated changes in the government deficit, i.e. deviations of the deficit from the expected path within a given policy regime. The foresight shock, by contrast, reflects changes in expectations about the future policy regime (see Appendix $\mathrm{C}$ for a plot of foresight shocks).

The model (4) is estimated with Bayesian methods with di use priors. 
Issue no. $25 / 2018$

\section{Results}

The presentation is organized by type of shock. For each country pair, we first consider the effects of a surprise shock as represented by a one percent rise in the realized de cit. Then, we consider a foresight shock as given by a one percent rise in the expected deficit as measured by (1), (2) or (3). For brevity, we report the impulse responses only for the model with the forecast error indicator. We have checked that using cumulated forecasts or forecast news is inconsequential for the analysis (Appendix B contains the impulse responses with (2) or (3)). In all Figures, impulse response functions are percent deviation from trend while shaded areas in dark grey and light grey represent, respectively, 68\% and 90\% confidence intervals. $^{12}$

Consider a fiscal expansion in Germany (Figure 1). Panels 1a and $1 \mathrm{~b}$ refer to the country pair Germany-Italy, while panels 1c and 1d refer to Germany-France. A nonanticipated rise in the German deficit, namely a surprise shock, has negative effects on economic activity both within and across German borders (Figures 1a and 1c). The response of German output is negative on impact in both samples, although it is barely significant in the sample Germany-Italy. Output returns to trend in about two years. Interestingly, the surprise expansion triggers expectations of substantial deficit reversals over the next two years: the forecast indicator falls on impact by approximately 0.5 percent below trend in both samples and turns slightly positive only after 2 years. Overall, these findings suggest that the effects of a surprise expansion today are completely o set by expectations of a deficit reversal in the near future.

A different picture emerges with foresight shocks (Figures $1 \mathrm{~b}$ and 1d). A positive shock to forecasts, i.e. an anticipated fiscal expansion, boosts output at home. The response of German output is positive on impact, reaches a peak of almost 0.8 percent after two years and then gradually returns to trend. The effect is quite persistent (about 4 years in the sample Germany-Italy and 3 years in the sample Germany-France). The multiplier - calculated as the cumulative increase in GDP - is above unity, precisely 1.4 percent in the sample GermanyItaly and 1 percent in Germany-France, in line with evidence about government spending

\footnotetext{
${ }^{12}$ Impulse responses are averages of the posterior distributions with 500 replications.
} 
Issue no. $25 / 2018$

multipliers cited above. It is worth stressing that the shock has a positive impact on domestic activity despite the deficit may actually fall below trend for a while.

Differently from surprise shocks, which imply sizable spillovers in the partner economies, the foresight shock has only minor consequences abroad. The response of GDP in either France or Italy is barely significant as are interest differentials. Bilateral exports increase as expected.

We have estimated the model for all of the other country pairs, considering a fiscal expansion in Italy (Figure 2) and a fiscal expansion in France (Figure 3).

Qualitatively, the responses are similar to those documented for a German expansion. Unanticipated fiscal expansions have negative output effects within and across borders (Figures $2 \mathrm{a}$ and $2 \mathrm{c}$ refer to a surprise shock in Italy; Figures $3 \mathrm{a}$ and $3 \mathrm{c}$ to a surprise shock in France). A surprise expansion in Italy (France) leads to a cumulated fall in domestic output as large as 0.7 percent (1.4 percent) over a 3 -year horizon. Output spillovers are negative in all country pairs. As before, the shock leads to large deficit reversals: the expected deficit falls by 1 percent ( 0.5 percent $)$ on impact in Italy (France) and is expected to stay below trend for about 3 years in both countries.

Turning to foresight shocks, domestic output increases in all samples, except France Italy (Figure 3d). Interestingly, the effect is independent of the dynamics of the realized deficit: the deficit moves in accord with expectations in the sample Italy-Germany, it moves in contrast with expectations in the sample France-Italy and barely reacts in all other cases. We stress that foresight shocks are much more effective within than across borders. As with a German fiscal expansion, output spillovers seem to occur mainly in response to surprise shocks.

Why are responses to surprise and forecast shocks so different? The reason is the effect on expectations. The surprise shock implies a deviation of the deficit from the expected path. Given the policy regime in place, the shock triggers expectations of deficit reversals. Agents form their expectations on the base of what they consider a credible fiscal regime. If they, for instance, believe that an increase in the government deficit today will lead to higher taxes in the future, then any unexpected fiscal stimulus will be completely o set by 
Issue no. $25 / 2018$

anticipated tax hikes. If, on the other side, agents believe that also spending cuts can be engineered to consolidate public debt, then expectations of a deficit reversal might have positive effects on aggregate demand and economic activity. The question of what type of fiscal regime is embodied in expectations is ultimately empirical. The evidence above is consistent with a regime where debt consolidation is mainly based on taxation.

The foresight shock, on the other side, implies a change in expectations, i.e. a regime shift that induces agents to revise their expectations. The fact that the foresight shock has positive effects on economic activity strengthens our argument that surprise shocks reflect a regime of tax-based debt consolidation. It is worth stressing that expectations seem to behave similarly in all countries despite ample heterogeneity in national fiscal regimes.

\section{Conclusions}

This paper has provided evidence in support of the hypothesis that fiscal policy is largely anticipated and its effects depend on expectations about future policy actions. Using the European Commission Forecasts of the government balance in France, Germany and Italy over the period 1971-2011, we have first assessed the forecast accuracy of the ECF in comparison to standard autoregressive models. Then, we have documented nonfundamentalness in the VAR model including, in this order, the government deficit (ratio to GDP) and GDP of the three countries taken one at a time, together with GDP, bilateral exports (ratio to GDP) and long-term interest rate differentials in each of the two partner economies considered in turn. The VAR model is estimated with Bayesian methods separately for each country pair. Finally, we have estimated a VAR model including, in addition to the variables above, one of three alternative forecast indicators: the cumulated forecast, the forecast error and the forecast news. Drawing on a recursive scheme, we have identified a surprise shock, i.e. an unanticipated deviation of the deficit from the expected path, and a foresight shock, i.e. a change in the expected deficit path.

We find that unanticipated fiscal stimulus generates expectations of strong deficit reversals over the next two to three years, depending on the country pair, and this depresses domestic and foreign activity over the same horizon. These dynamics are consistent with a 
regime where deficit reversals are mainly based on taxation and crowdout private expenditure. A regime shift that leads agents to anticipate a (credible) fiscal expansion, on the contrary, has positive effects on domestic activity. Differences in the responses to surprise and foresight shocks reflect the role of expectations about the policy regime that will prevail in the future. Our results suggest that fiscal stimulus is ineffective as long as the current regime is expected to be in place also in the future.

The evidence in this paper has non-negligible policy implications. First, it supports the idea that fiscal stimulus is effective as long as it triggers expectations of deficit reversals which are not entirely tax-driven. Remarkably, this would require a credible regime shift for all countries in our sample. Second, it suggests that the incentive to reform fiscal regimes in an uncoordinated way may be small. On the one side, the incentives for opportunistic behavior may be strong. Negative output spillovers in response to surprise shocks imply, in fact, that the adverse effects of deficit reversals can be partly shifted abroad. On the other side, changes in expectations have only minor consequences for foreign activity. 

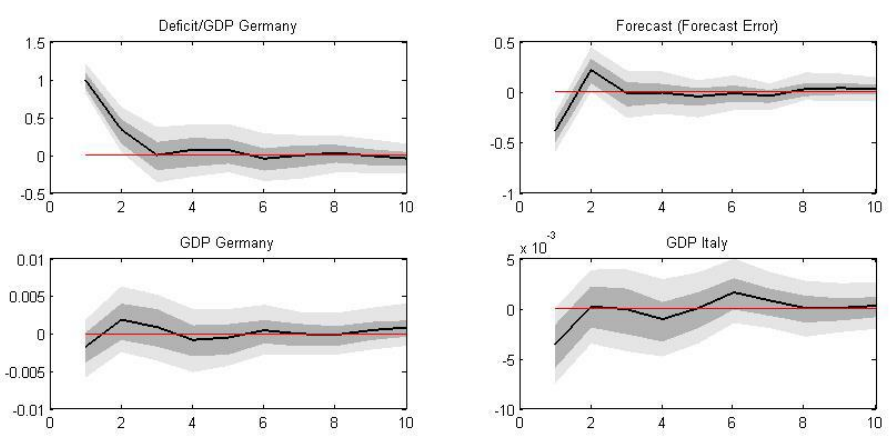

Real Net Expo Italy $\rightarrow \rightarrow$ Germany
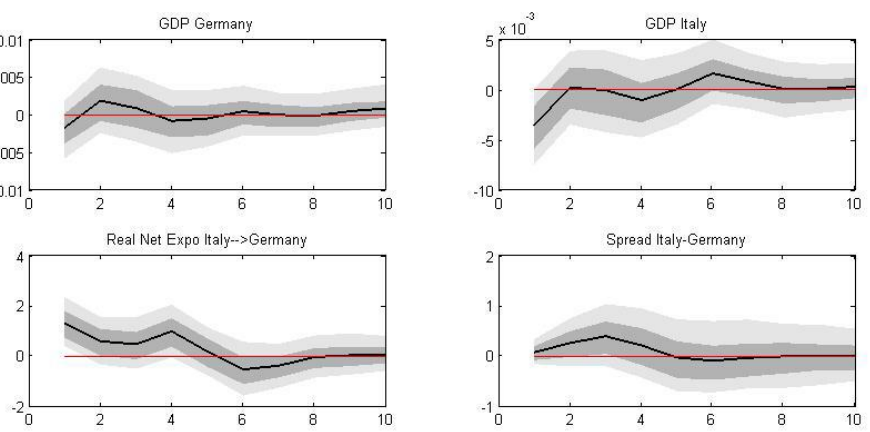

(a) IRF to a $1 \%$ rise in Deficit. Germany - Italy
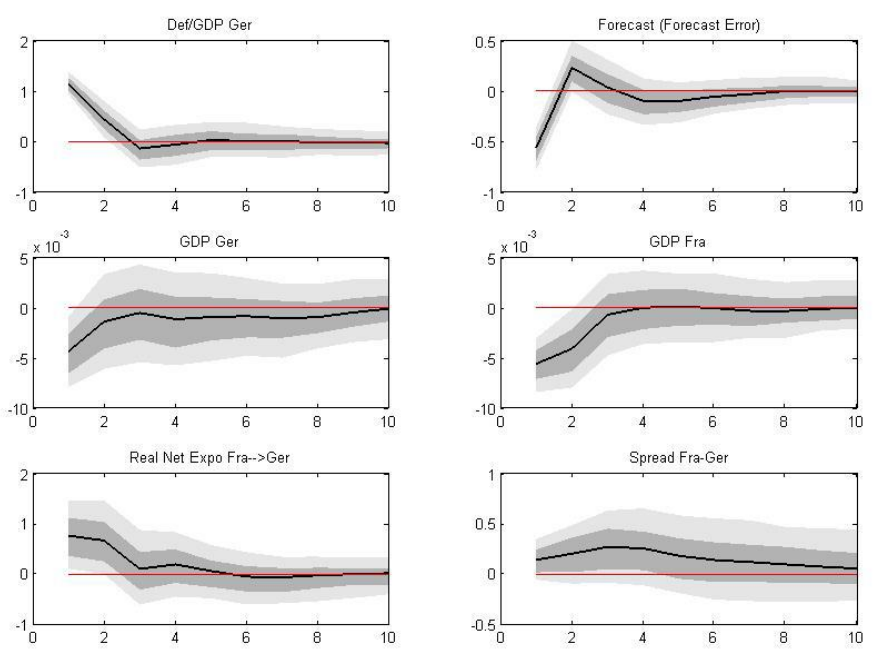

(c) IRF to a $1 \%$ rise in Deficit. Germany - France
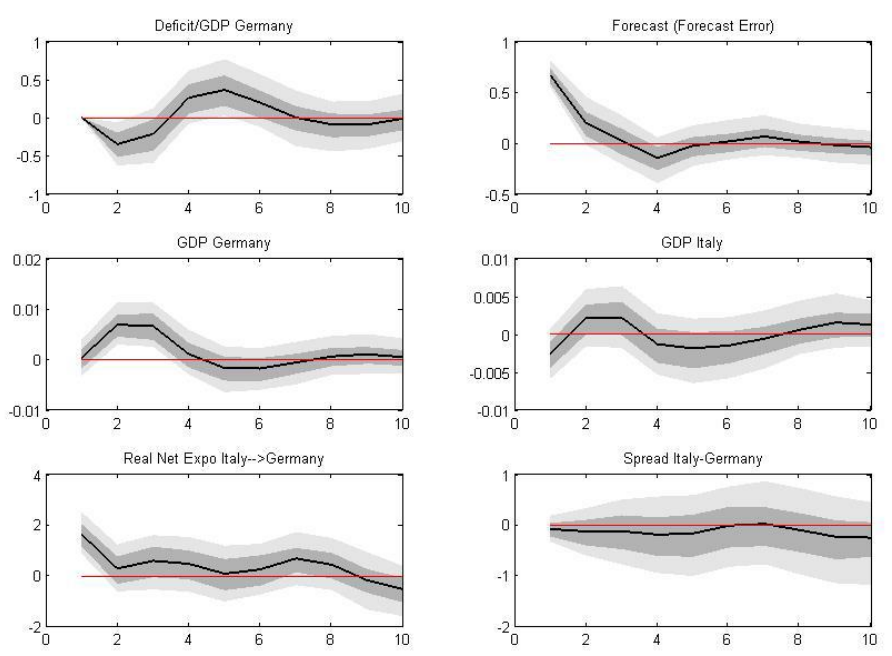

(b) IRF to a $1 \%$ rise in Foresight Deficit. Germany - Italy
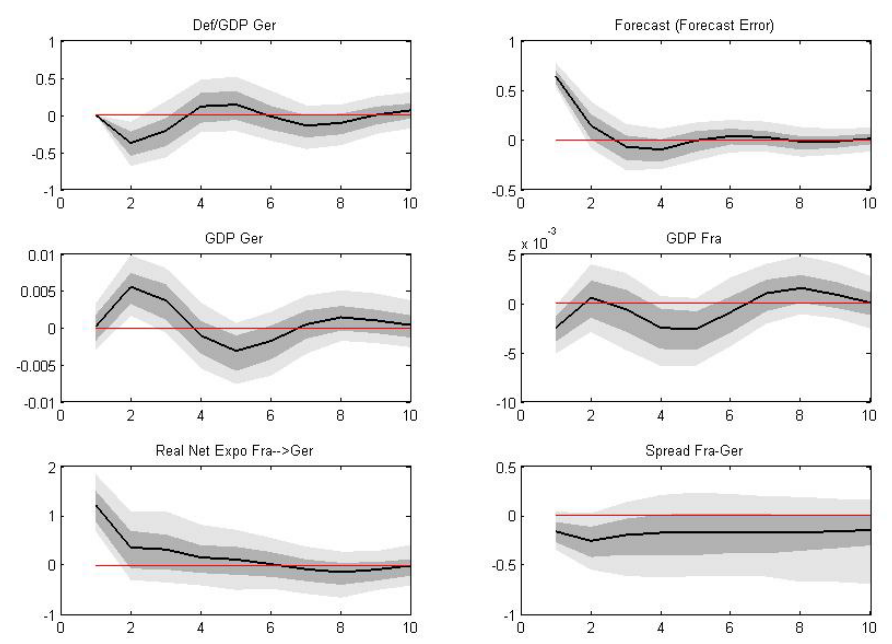

(d) IRF to a $1 \%$ rise in Foresight Deficit. Germany - France

Figure 1: Domestic and cross-border effects of a fiscal expansion in Germany 

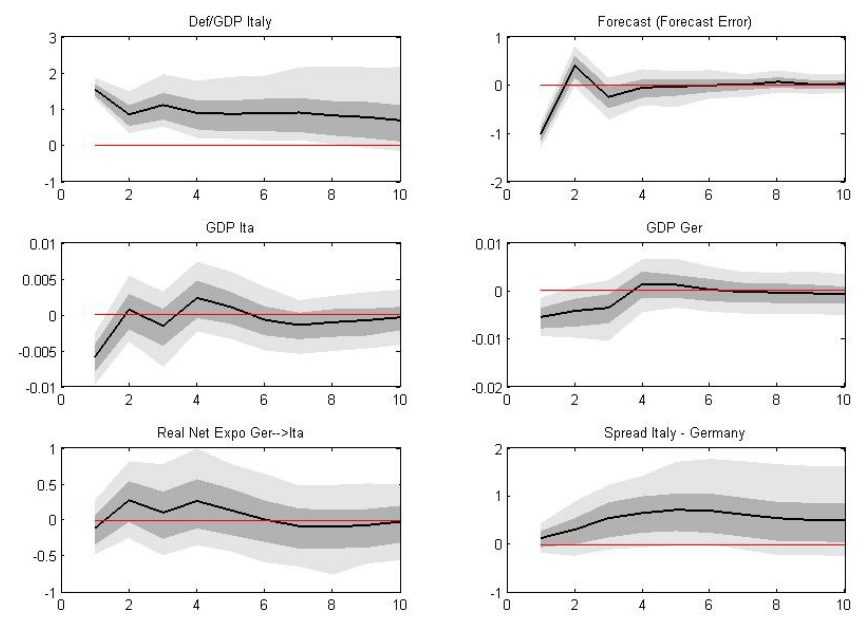

(a) IRF to a $1 \%$ rise in Deficit. Italy - Germany
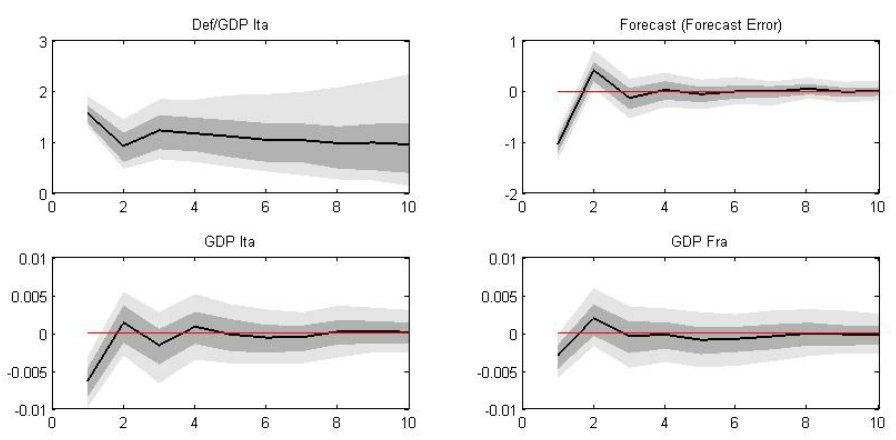

Real Net Expo Fra-->ita
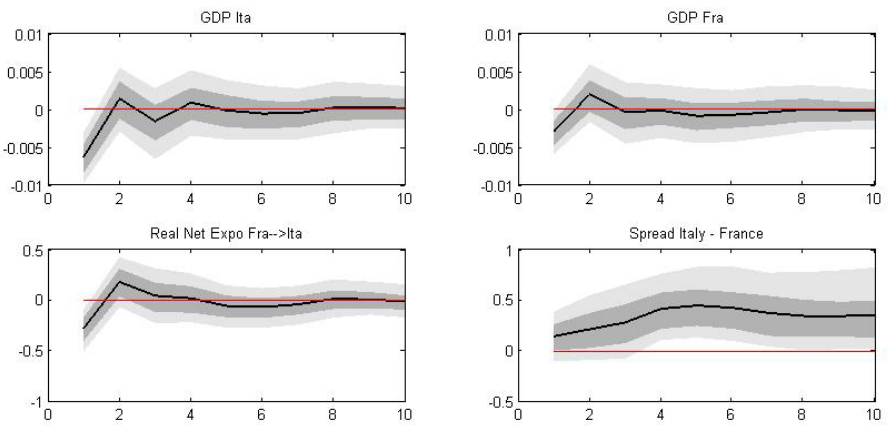

(c) IRF to a $1 \%$ rise in Deficit. Italy - France
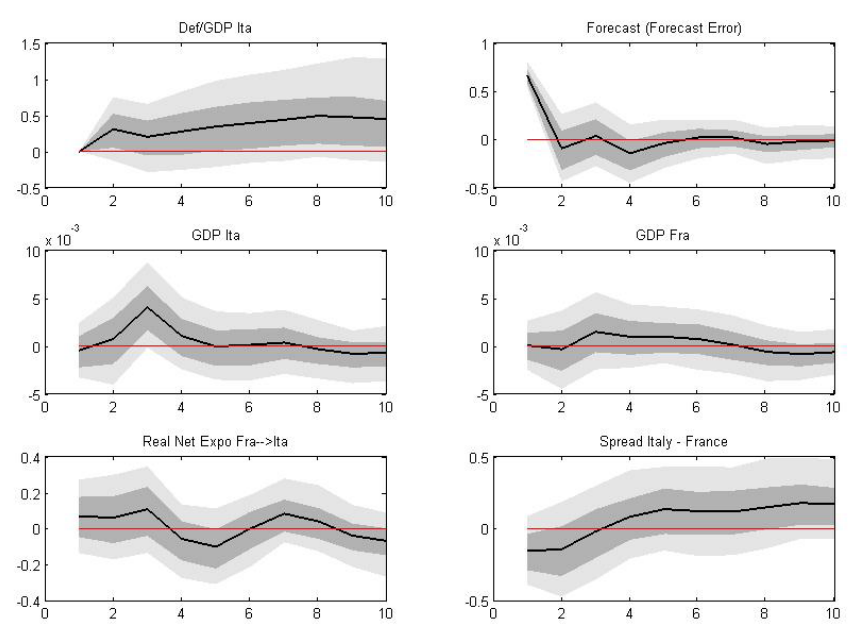

(b) IRF to a $1 \%$ rise in Foresight Deficit. Italy - Germany
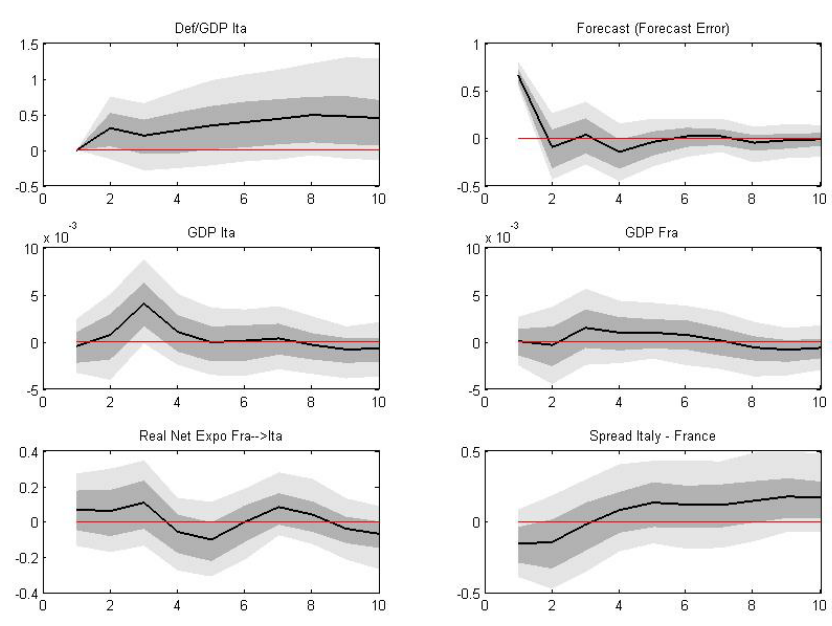

(d) IRF to a $1 \%$ rise in Foresight Deficit. Italy - France

Figure 2: Domestic and cross-border effects of a fiscal expansion in Italy 
Issue no. $25 / 2018$
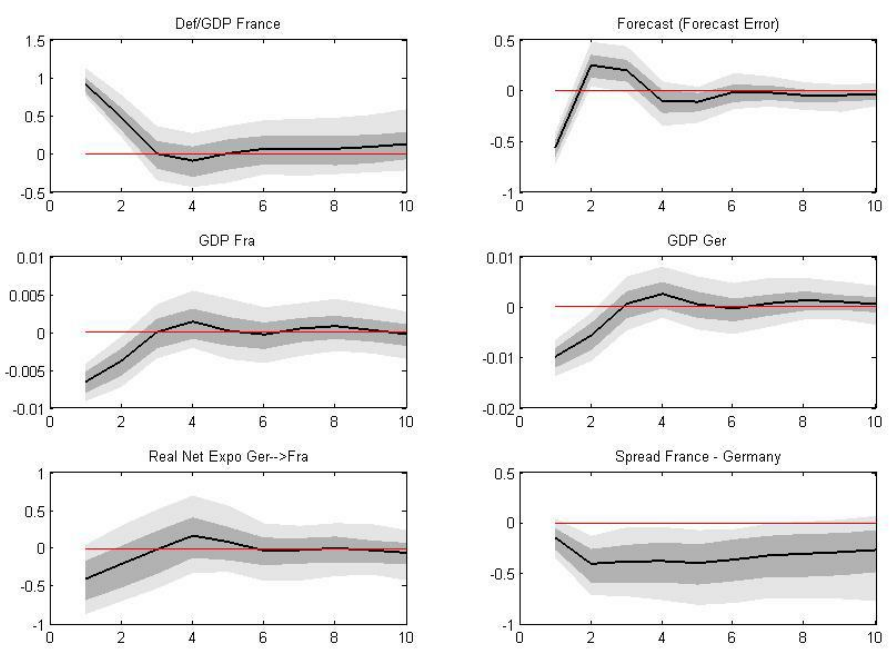

(a) IRF to a $1 \%$ rise in Deficit. France - Germany
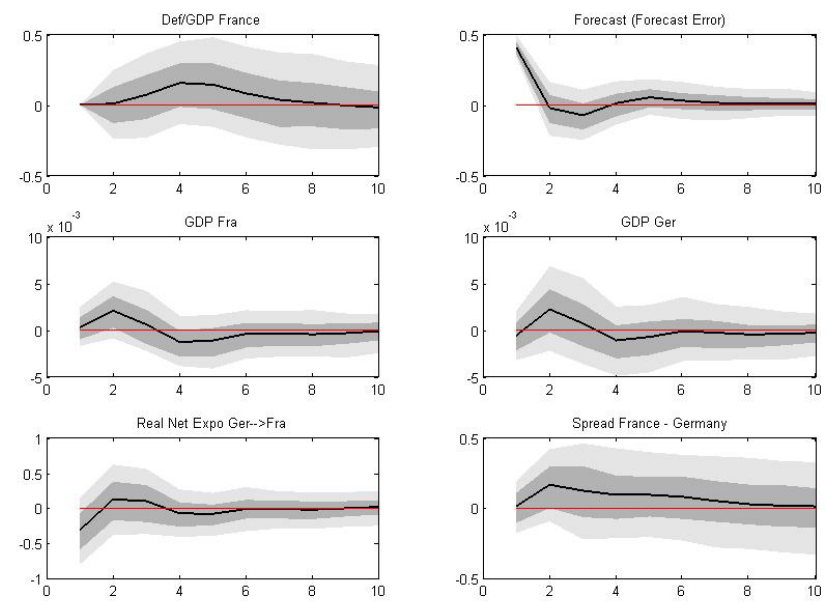

Spread France - Germany

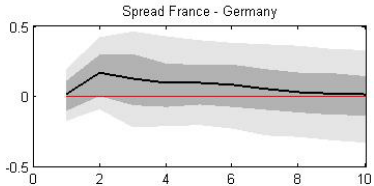

(b) IRF to a $1 \%$ rise in Foresight Deficit. France - Germany
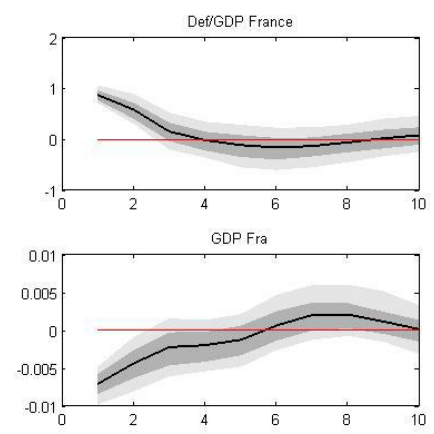

Real Net Expo lta- $>$ Fra

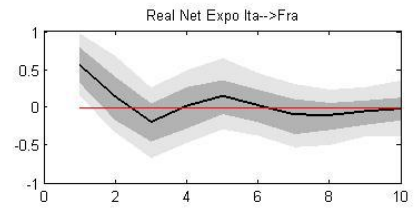

(c) IRF to a $1 \%$ rise in Deficit. France - Italy
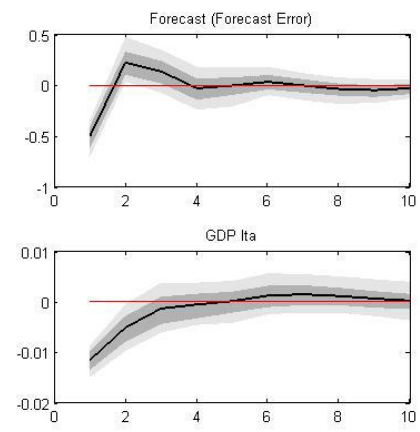

Spread thaly - France

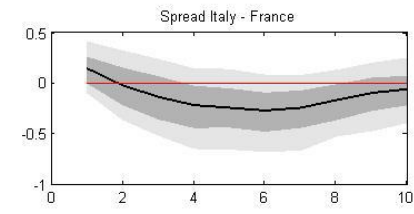

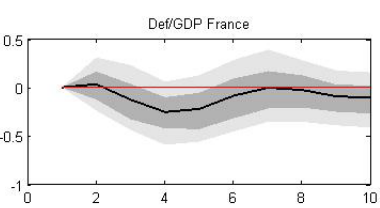

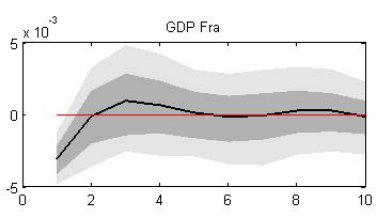

Real Net Expo Ita- $\rightarrow$ Fra
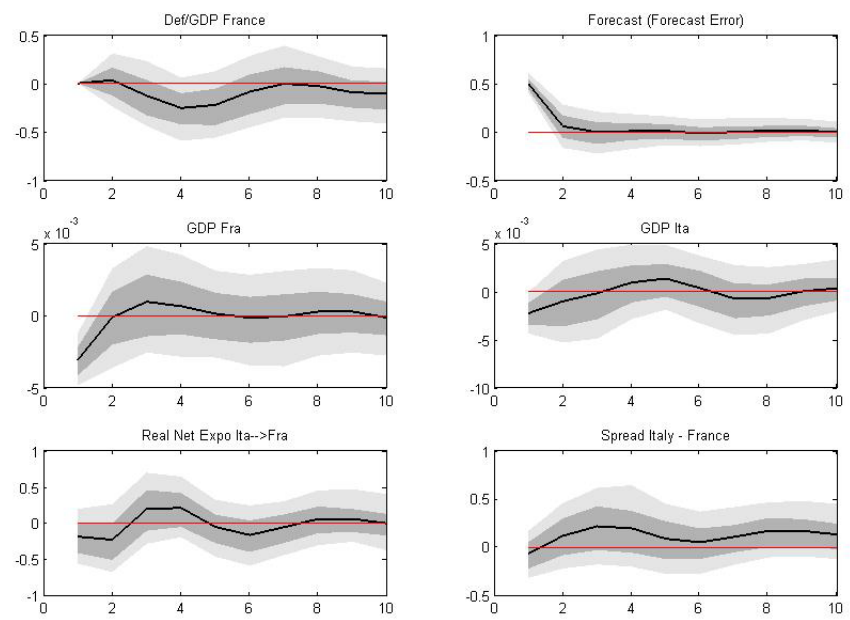

Spread Italy - France

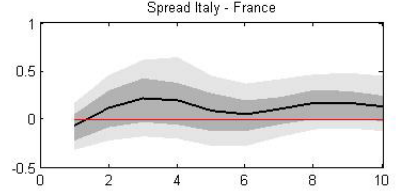

(d) IRF to a $1 \%$ rise in Foresight Deficit. France - Italy

Figure 3: Domestic and cross-border effects of a fiscal expansion in France 
Issue no. $25 / 2018$

\section{References}

1. ALESINA, A. AND ARDAGNA, S. (2010), Large Changes in Fiscal Policy: Taxes versus Spending, NBER Chapters: Tax Policy and the Economy, Vol. 24, pp. 35-68

2. ALESINA, A., BARBIERO, O., FAVERO, C., GIAVAZZI, F. and PARADISI, M. (2015), Austerity in 2009-2013, NBER Working Papers No. 20827

3. AUERBACH, A. J. and GORODNICHENKO, Y. (2012), Fiscal Multipliers in Recession and Expansion, NBER Chapters: Fiscal Policy after the Financial Crisis, pp. 6398

4. AUERBACH, A. J. and GORODNICHENKO, Y. (2013), Output Spillovers from Fiscal Policy, American Economic Review, Vol. 103 (May), pp. 141-46

5. BEETSMA, R. and GIULIODORI, M. (2004), What are the Spillovers from Fiscal Shocks in Europe? An Empirical Analysis, ECB Working Paper, No. 325

6. BEETSMA, R., GIULIODORI, M. and KLAASSEN, F. (2006), Trade Spillovers of Fiscal Policy in the European Union: A Panel Analysis, Economic Policy, Vol. 21(48), pp. 639-687

7. BERNANKE, B. S. (2012), Some Reflections on the Crisis and the Policy Response, Remarks at the Conference on Rethinking Finance: Perspectives on the Crisis

8. BLANCHARD, O.J. and PEROTTI R. (2002), An Empirical Characterization of the Dynamic Effects of Changes in Government Spending and Taxes on Output, The Quarterly Journal of Economics, Vol. 117(4), pp. 1329-1368

9. BOUSSARD, J., DE CASTRO, F. and SALTO, M. (2012), Fiscal Multipliers and Public Debt Dynamics in Consolidations, Economic Papers 460 (July), Directorate General Economic and Monetary A airs (DG ECFIN), European Commission

10. BURNSIDE, C. and MESHCHERYAKOVA, Y. (2004), Cyclical Adjustment of the Budget Surplus: Concepts And Measurement Issues, Fiscal Sustainability in Theory and Practice: A Handbook, pp. 113-132, World Bank

11. CAgGiano, G., CASTElnUOVO, E., COLOMBO, V. and NODARI, G. (2014), Estimating Fiscal Multipliers: News from a Nonlinear World, Melbourne Institute Working Paper Series wp2014, No. 26 
Issue no. $25 / 2018$

12. CAPORALE, G.M. and GIRARDI, A. (2013), Fiscal Spillovers in the euro area, Journal of International Money and Finance, Vol. 38(C)

13. CANZONERI, M., COLlARD, F., DELlAS, H. and DIBA, B. (2015), Fiscal Multipliers in Recessions, CEPR Discussion Papers 10353

14. CHINN, M. (2013), Fiscal Multipliers, contribution to the New Palgrave Dictionary of Economics

15. COGAN, J., CWIK, T., TAYLOR J. and WIELAND, G. (2010), New Keynesian versus Old Keynesian Government Spending Multiplier, Journal of Economic Dynamics and Control, Vol. 34(3), pp. 281-295

16. CORSETTI, G., MEIER, A. and MULLER, G. (2010), Cross-Border Spillovers from Fiscal Stimulus, International Journal of Central Banking, Vol. 6(1), pp. 5-37

17. CORSETTI, G., MEIER, A. and MULLER, G. (2012), What determines government spending multipliers?, Economic Policy, Vol. 27(72), pp. 521-565

18. D'AGOSTINO, A. and CIMADOMO, J. (2013), Combining time-variation and mixed frequencies: an analysis of government spending multipliers in Italy, Working Paper Series 1856, European Central Bank

19. DE ARCANGELIS, G. and LAMARTINA, S. (2004), Fiscal shocks and policy regimes in some OECD countries, Monetary Policy, Fiscal Policies and Labour Market, Cambridge University Press.

20. DEVRIES, P., GUAJARDO J., LEIGH D. and PESCATORI, A. (2011), A New Action-Based Dataset of Fiscal Consolidation, IMF Working Papers 11/128, International Monetary Fund

21. DORNBUSCH, R. (1976), Expectations and exchange rates dynamics, Journal of Political Economy 84, pp. 1161-1176

22. FACCINI, R., MUMTAZ, H. and SURICO, P. (2012), Testing for International Fiscal Spillovers, LBS manuscript

23. FATAS A. and MIHOV I. (2001), The Effects of Fiscal Policy on Consumption and Employment: Theory and Evidence, CEPR Discussion Papers No. 2760

24. FORNI, M. and GAMBETTI, L. (2014), Government Spending Shocks in Open Economy VARs, CEPR Discussion Papers 10115 
Issue no. $25 / 2018$

25. GONZALEZ CABANILLAS, L. and TERZI, A. (2012), The accuracy of the European Commission's forecasts re-examined, European Commission Economic Paper No. 476

26. GROSSMAN, E. and WOLL, C. (2014), Saving the Banks: The Political Economy of Bailouts, Comparative Political Studies, Vol. 47, No. 4, pp. 574-600

27. GUAJARDO, J., LEIGH, D. and PESCATORI, A. (2011), Expansionary Austerity: New International Evidences, Journal of the European Economic Association 12, pp. 949968

28. ILZETZKI, E. O., MENDOZA, E., and VEGH, C. (2013). How big (small?) are fiscal multipliers?, Journal of Monetary Economics, Vol. 60(2), pp. 239-254

29. KYDLAND, F. and PRESCOTT, E. (1977), Rules Rather Than Discretion: The Inconsistency of Optimal Plans, Journal of Political Economy, Vol. 85(3), pp. 473-91

30. KIM, S. and ROUBINI N. (2008), Twin de cit or twin divergence? Fiscal policy, current account, and real exchange rate in the U.S, Journal of International Economics 74(2), pp. $362-383$

31. LEEPER, E.M., A. W. RICHTER, and WALKER T. B. (2012), Quantitative Effects of Fiscal Foresight, American Economic Journal: Economic Policy, Vol. 4(2), pp. 115-144 32. LEEPER, E.M., WALKER, T.B. and YANG, S.S. (2008), Fiscal Foresight: Analytics and Econometrics, NBER Working Paper No. 14028

33. MIRDALA R. (2009), Effects Of Fiscal Policy Shocks In The European Transition Economies, Journal of Applied Research in Finance Bi-Annually, Vol. 0(2), pp. 141157

34. MONACELli, T. and PEROTTI, R. (2010), Fiscal Policy, the Real Exchange Rate and Traded Goods, Economic Journal, Vol. 120(544), pp. 437-461

35. OSTRUP, F., OXELHEIM L. and WIHLBORG C. (2009), Origins and Resolution of Financial Crises: Lessons from the Current and Northern European Crises, Asian Economic Papers, Vol. 8(3), pp. 178-220

36. PEROTTI, R. (2011), Expectations and Fiscal Policy: An Empirical Investigation, IGIER working paper No 429

37. RAMEY, V.A. (2011a), Identifying Government Spending Shocks: It's All in the Timing, The Quarterly Journal of Economics, Vol. 126(1), pp. 1-50 
Issue no. $25 / 2018$

38. RAMEY, V.A. (2011b), Can Government Purchases Stimulate the Economy?, Journal of Economic Literature, Vol. 49(3), pp. 673-85

39. REICHLIN, L. (2014), Monetary Policy and Banks in the Euro Area: The Tale of Two Crises, Journal of Macroeconomics, Vol. 39, pp. 387-400

40. RODRIGUEZ, C. and CARRASCO, C.A. (2014), ECB Policy Responses between 2007 and 2014: a chronological analysis and a money quantity assessment of their effects, Working papers 65, Financialisation, Economy, Society and Sustainable Development (FESSUD) Project

41. UHLIG, H. (2006), What are the effects of monetary policy on output? Results from an agnostic identification procedure, Journal of Monetary Economics, Vol. 52(2), pp. 381419

42. VAN DER NOORD, P. (2000), The Size and Role of Automatic Fiscal Stabilizers in the 1990s and Beyond, OECD Economics Department Working Papers 230

43. IN 'T VELD, J. (2013), Fiscal consolidations and spillovers in the Euro area periphery and core, European Economy - Economic Papers 506, Directorate General Economic and Monetary A airs (DG ECFIN), European Commission

44. IN 'T VELD, J., LARCH, M. and VANDEWEYER, M. (2013), Automatic Fiscal Stabilisers: What They Are and What They Do, Open Economies Review, Vol. 24(1), pp. $147-163$

45. WOODFROD, M. (2011), Simple Analytics of the Government Expenditure Multiplier, American Economic Journal: Macroeconomics, Vol. 3(1), pp. 1-35

46. YANG, S.S. (2008), Quantifying tax effects under policy foresight, Journal of Monetary Economics 52(8), pp. 1557-1568 
Issue no. $25 / 2018$

A Appendix

Table 3: Data

Series

Gov. Balance/GDP

Gov. Balance/GDP Forecast

Real GDP

(B1_GA)

Bilateral Exports

Bilateral Imports

CPI - All Items

Euro - Dollar Exchange Rate

(ert_bil_eur_a)

Gov. Bonds Interest Rates

$\mathrm{IMF}$

\section{Unit of measure}

EU Commission* $\%$

$* *$

EU Commission* $\quad \% \quad * *$

OECD StatExtract Millions of Euros - 2010 Base Year

$(\mathrm{VOB})$

WITS UN ComTrade Dollars

$* *$

WITS UN ComTrade Dollars

**

OECD StatExtract $\quad 2010=100$

Eurostat $\quad 1 \mathrm{e}=\quad \$$

$\%$

* See Gonzalez Cabanillas, L. and Terzi, A. (2012)

** HP tered with a smoothing parameter $\lambda=6.5$ 
Issue no. $25 / 2018$

B Appendix

B.1

Model with cumulated forecasts
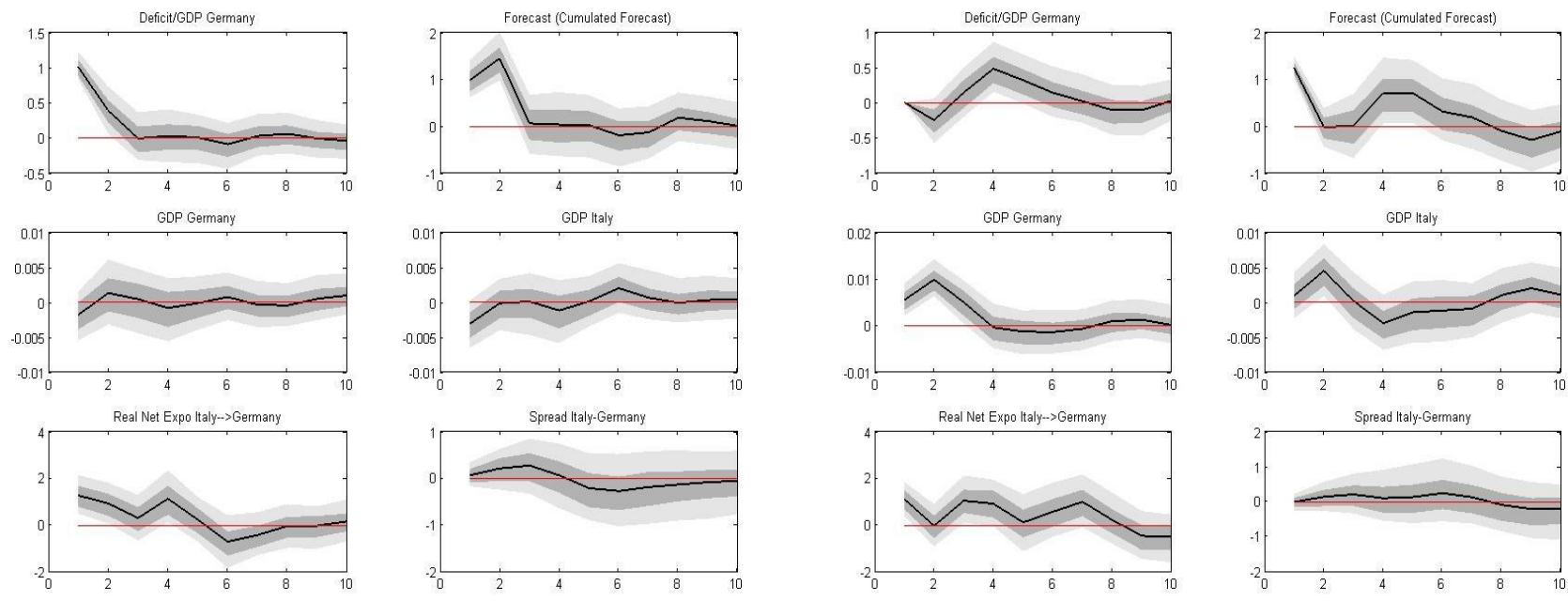

(a) IRF to a $1 \%$ rise in Deficit. Germany - Italy

(b) IRF to a $1 \%$ rise in Foresight Deficit. Germany - Italy
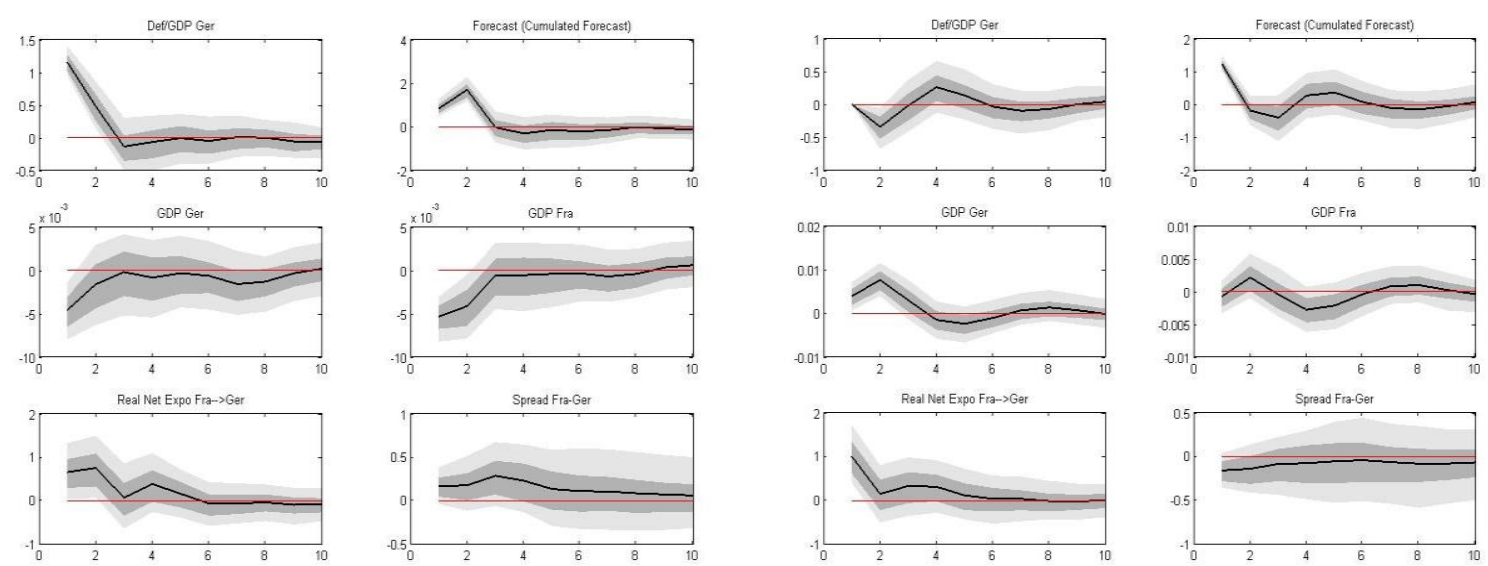

(c) IRF to a $1 \%$ rise in Deficit. Germany - France

(d) IRF to a $1 \%$ rise in Foresight Deficit. Germany - France

Figure 4: Domestic and cross-border effects of a fiscal expansion in Germany 

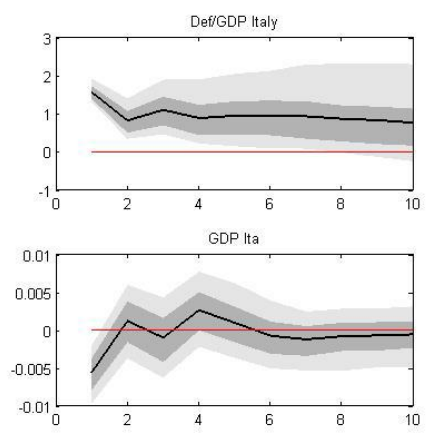

Real Net Expo Ger->lta
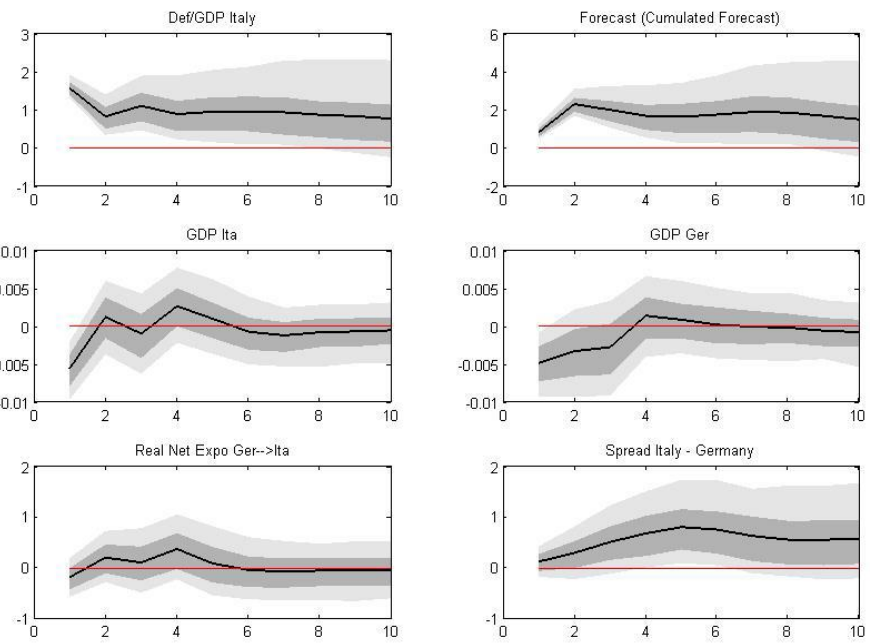

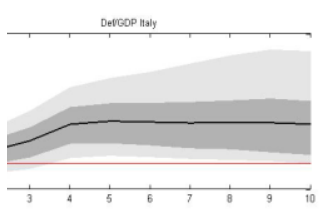

GOP R:

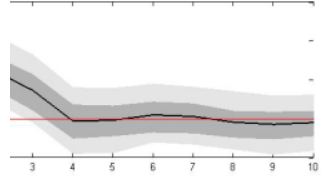

Real Net Expo Otom-that

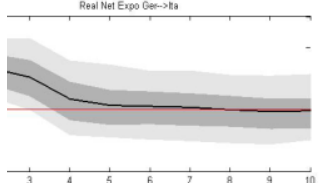

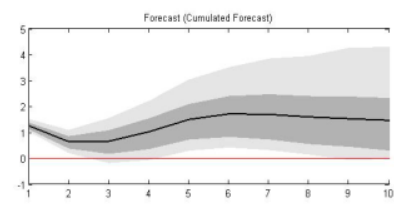

GOP Get

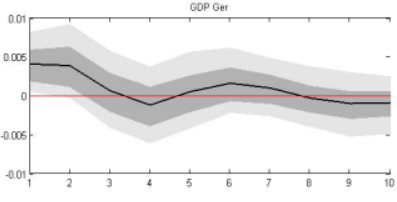

Seress tayl - Germas

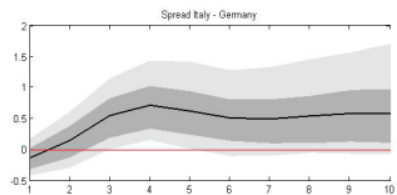

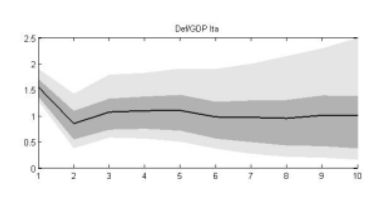

Gopt
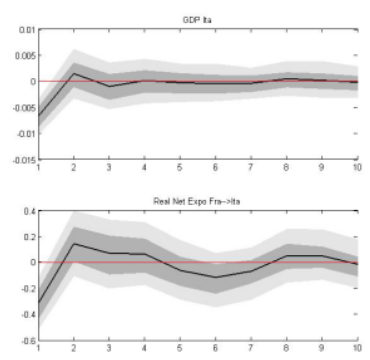

(c) IRF to a $1 \%$ rise in Deficit. Italy - France
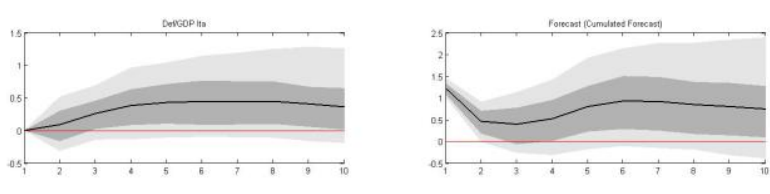

sop fin
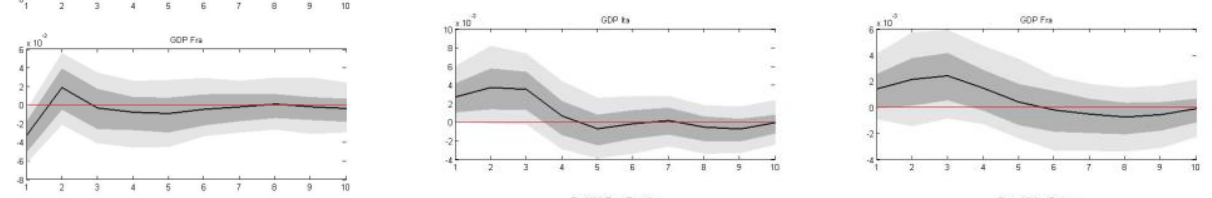

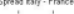
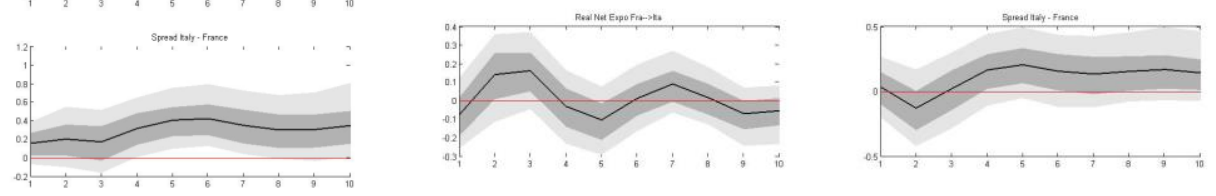

(d) IRF to a $1 \%$ rise in Foresight Deficit. Italy - France

Figure 5: Domestic and cross-border effects of a fiscal expansion in Italy 

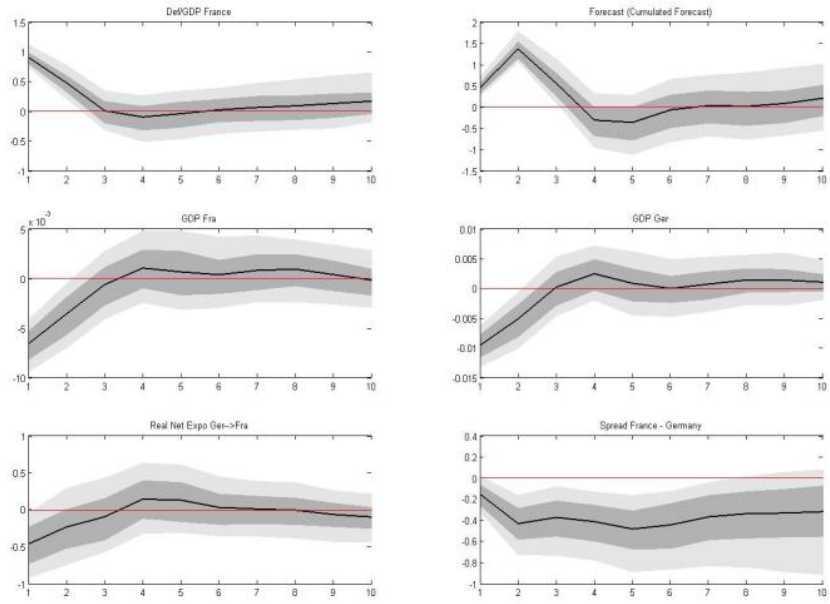

(a) IRF to a $1 \%$ rise in Deficit. France - Germany
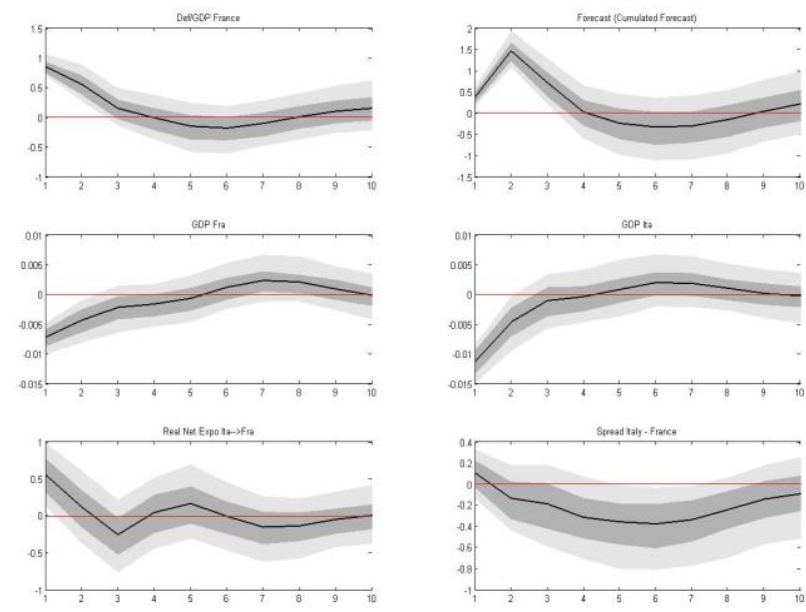

(c) IRF to a $1 \%$ rise in Deficit. France - Italy
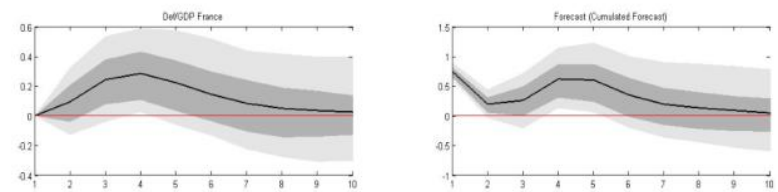

Gop Fin
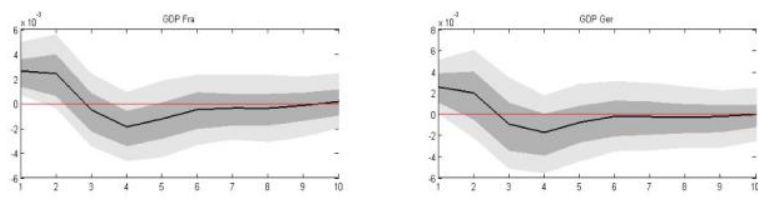

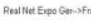

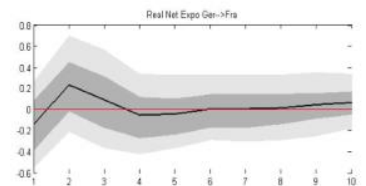

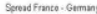

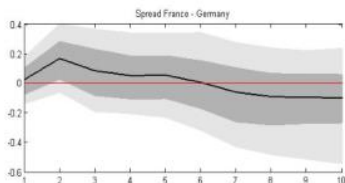

(b) IRF to a $1 \%$ rise in Foresight Deficit. France - Germany
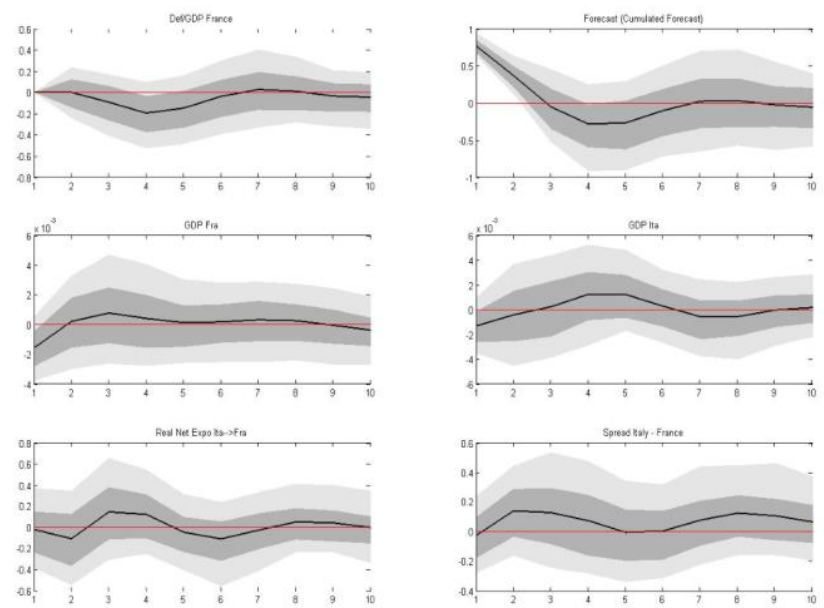

(d) IRF to a $1 \%$ rise in Foresight Deficit. France - Italy

Figure 6: Domestic and cross-border effects of a fiscal expansion in France 
Issue no. $25 / 2018$

B.2

Model with forecast news
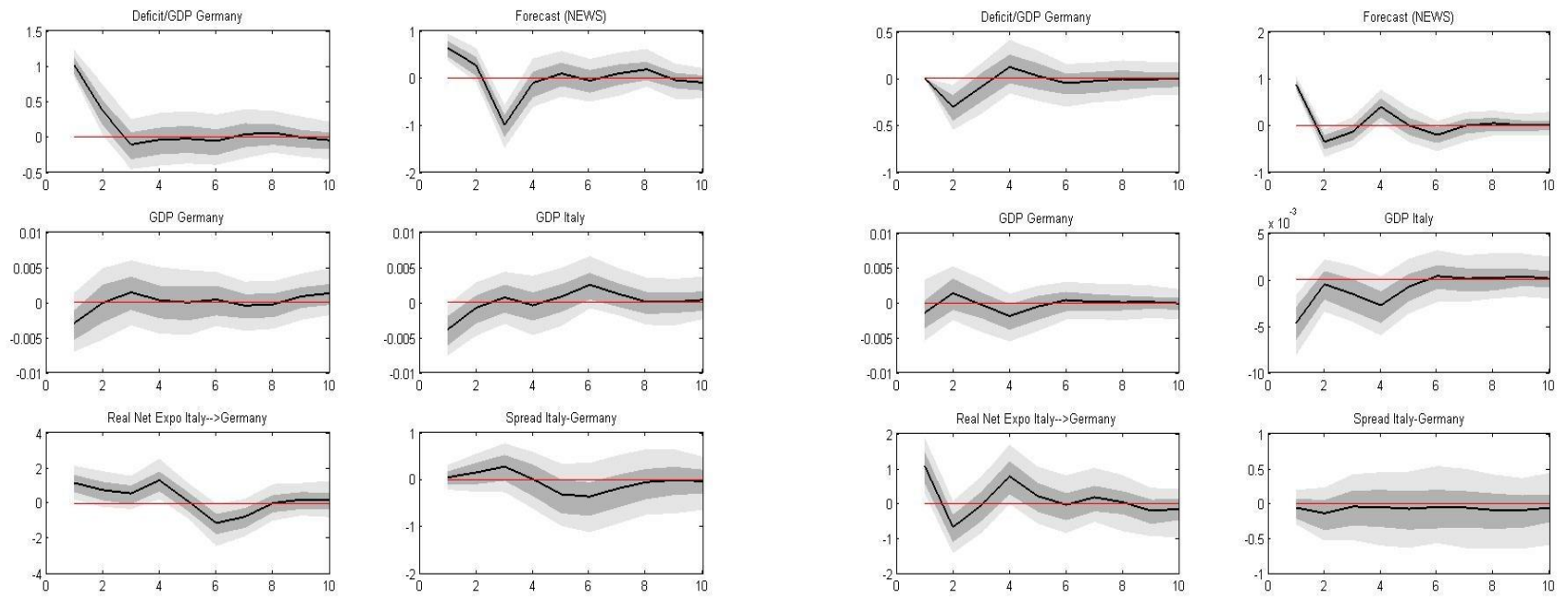

(a) IRF to a $1 \%$ rise in Deficit. Germany - Italy

(b) IRF to a $1 \%$ rise in Foresight Deficit. Germany - Italy
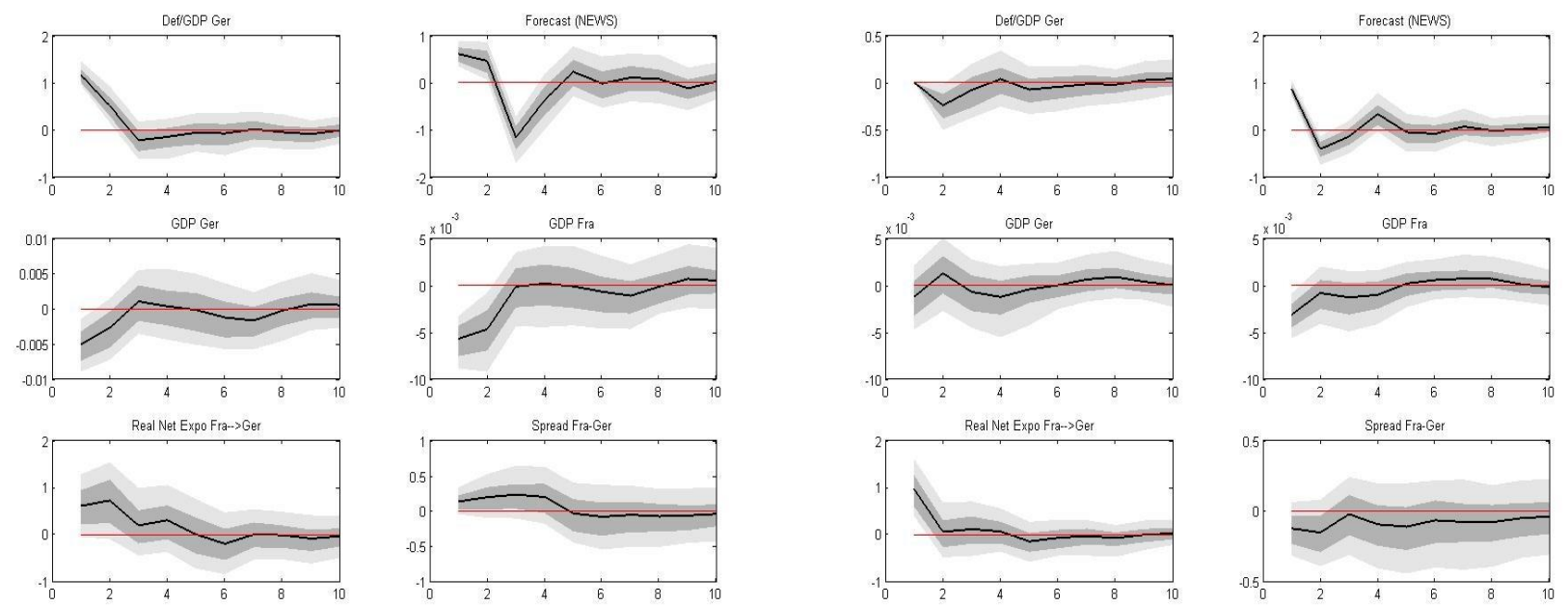

(c) IRF to a $1 \%$ rise in Deficit. Germany - France

(d) IRF to a $1 \%$ rise in Foresight Deficit. Germany - France

Figure 7: Domestic and cross-border effects of a fiscal expansion in Germany 

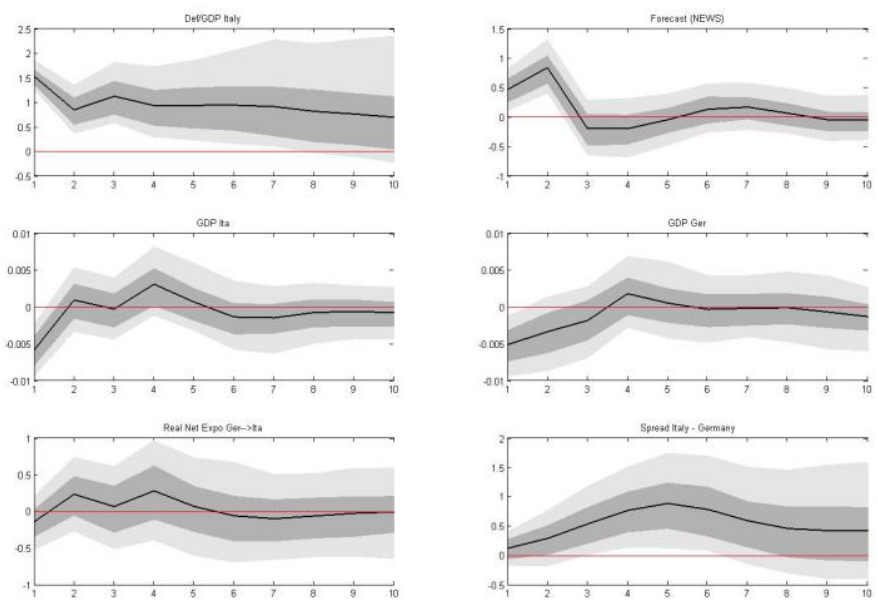

(a) IRF to a $1 \%$ rise in Deficit. Italy - Germany
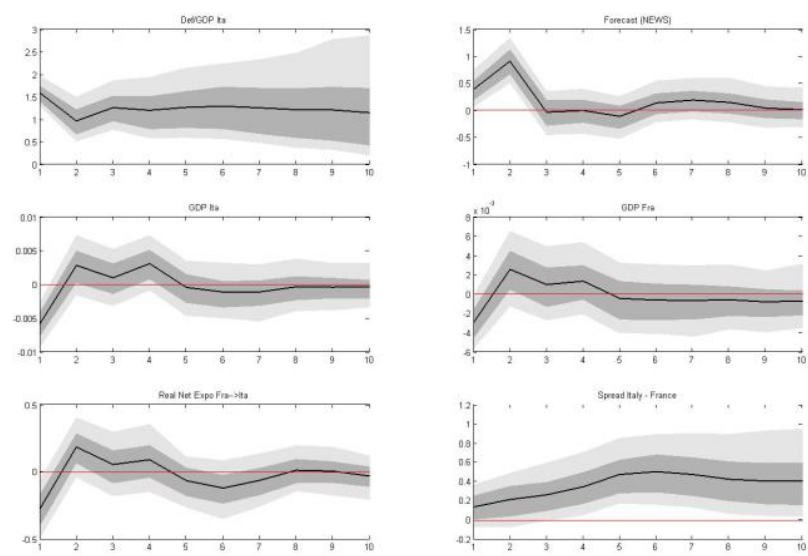

(c) IRF to a $1 \%$ rise in Deficit. Italy - France
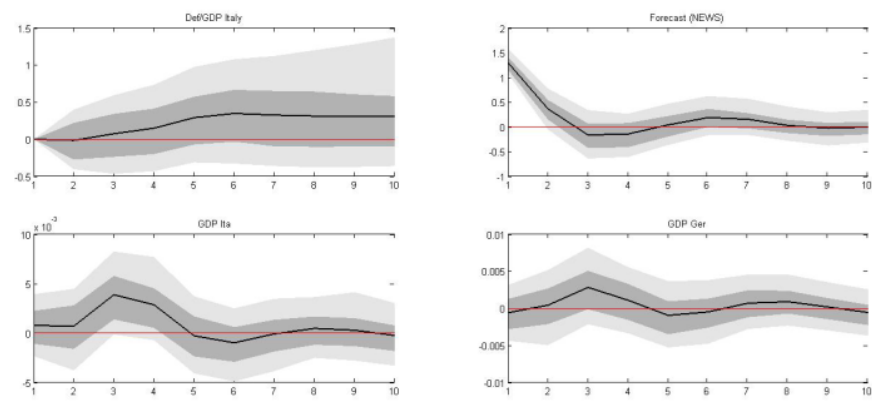

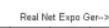
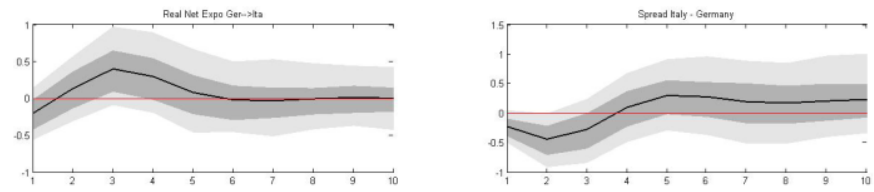

(b) IRF to a $1 \%$ rise in Foresight Deficit. Italy - Germany
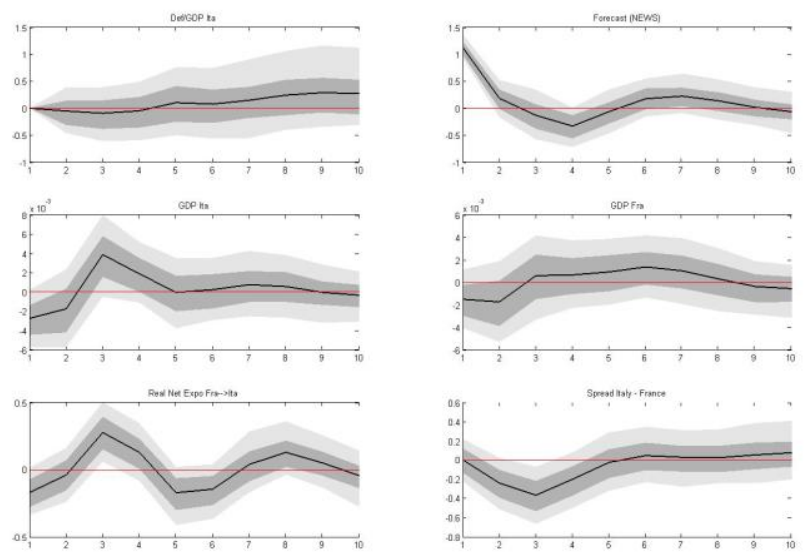

(d) IRF to a $1 \%$ rise in Foresight Deficit. Italy - France

Figure 8: Domestic and cross-border effects of a fiscal expansion in Italy 

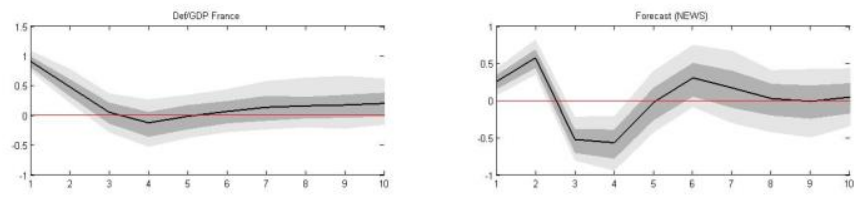

Gop Fa,

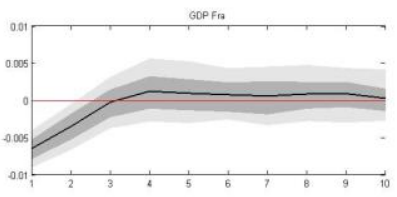

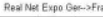
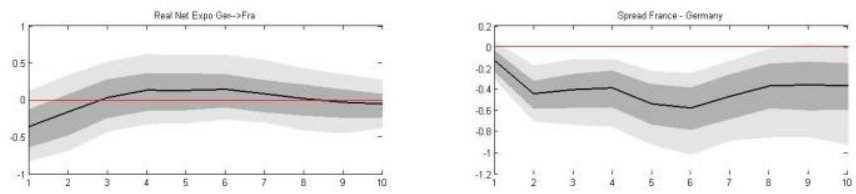

(a) IRF to a $1 \%$ rise in Deficit. France - Germany
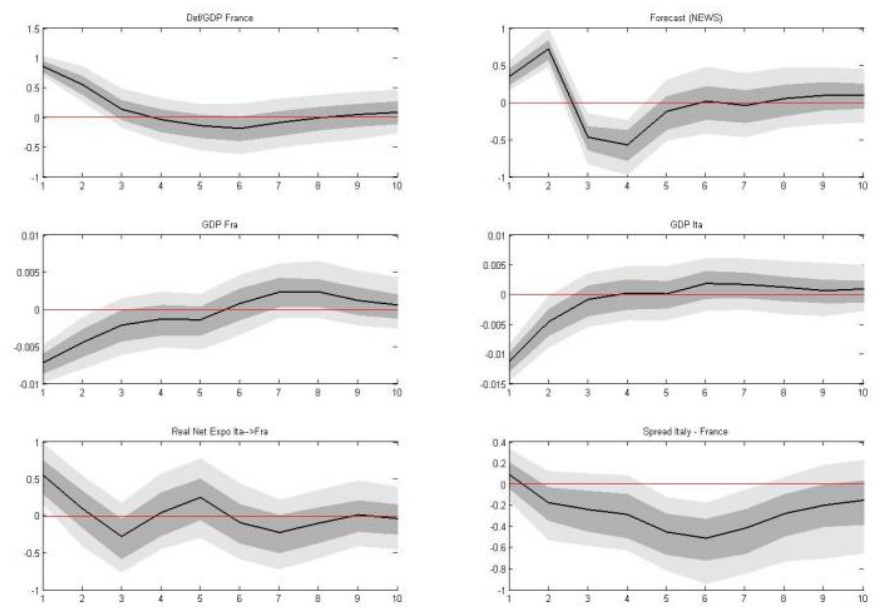

(c) IRF to a $1 \%$ rise in Deficit. France - Italy
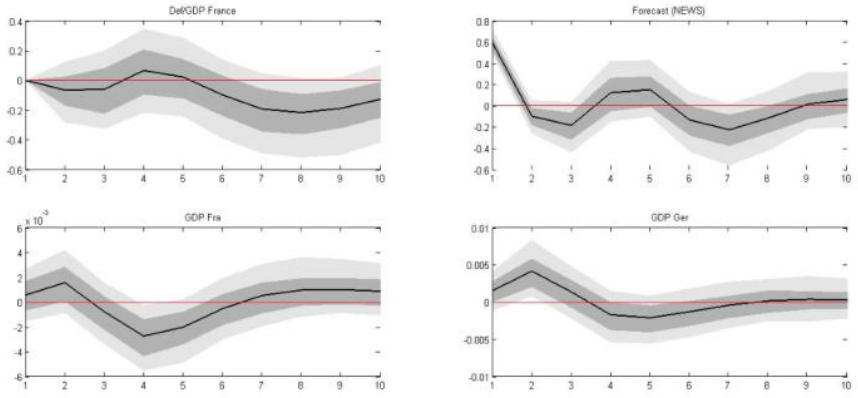

Rast hat Enpo Geer-ifia

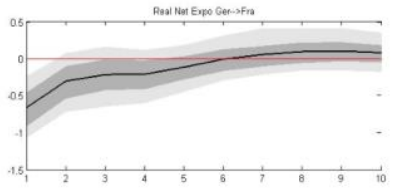

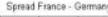

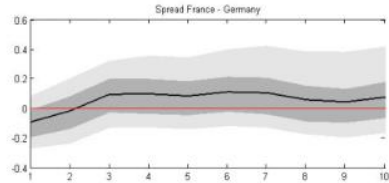

(b) IRF to a $1 \%$ rise in Foresight Deficit. France - Germany
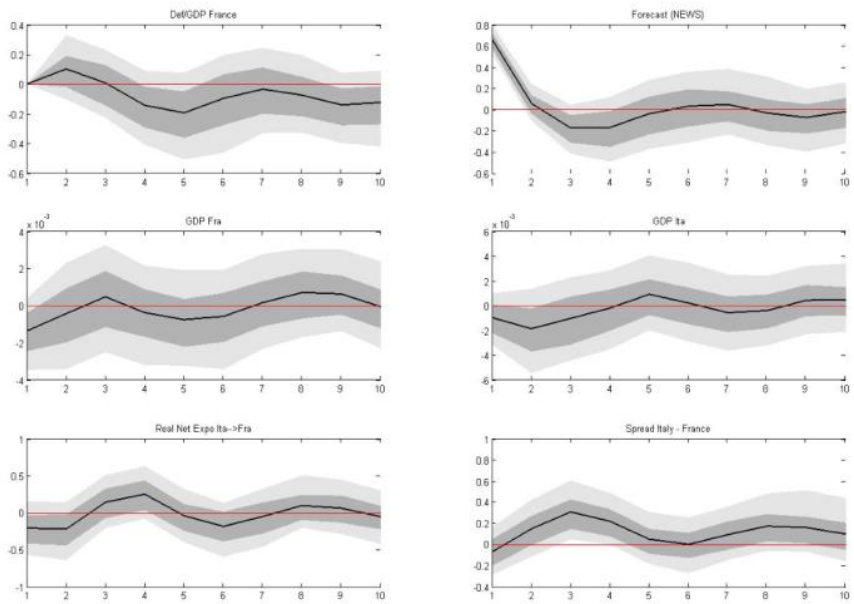

Speesd haly, Fance

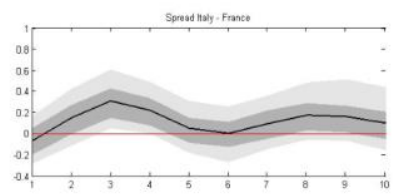

(d) IRF to a $1 \%$ rise in Foresight Deficit. France - Italy

Figure 9: Domestic and cross-border effects of a fiscal expansion in France 
Issue no. $25 / 2018$

\section{Appendix}

Consider foresight shocks. Figures 10 to 15 plot for each country pair the foresight shocks obtained from the model with cumulated forecasts, with forecast errors or with forecast news. The red shaded areas represent period of sizable fiscal consolidations, de ned as deficit reductions above 0.5 of GDP as in Devries et al. (2011). Positive (negative) values reflect a revision upward (downward) of the deficit forecast.
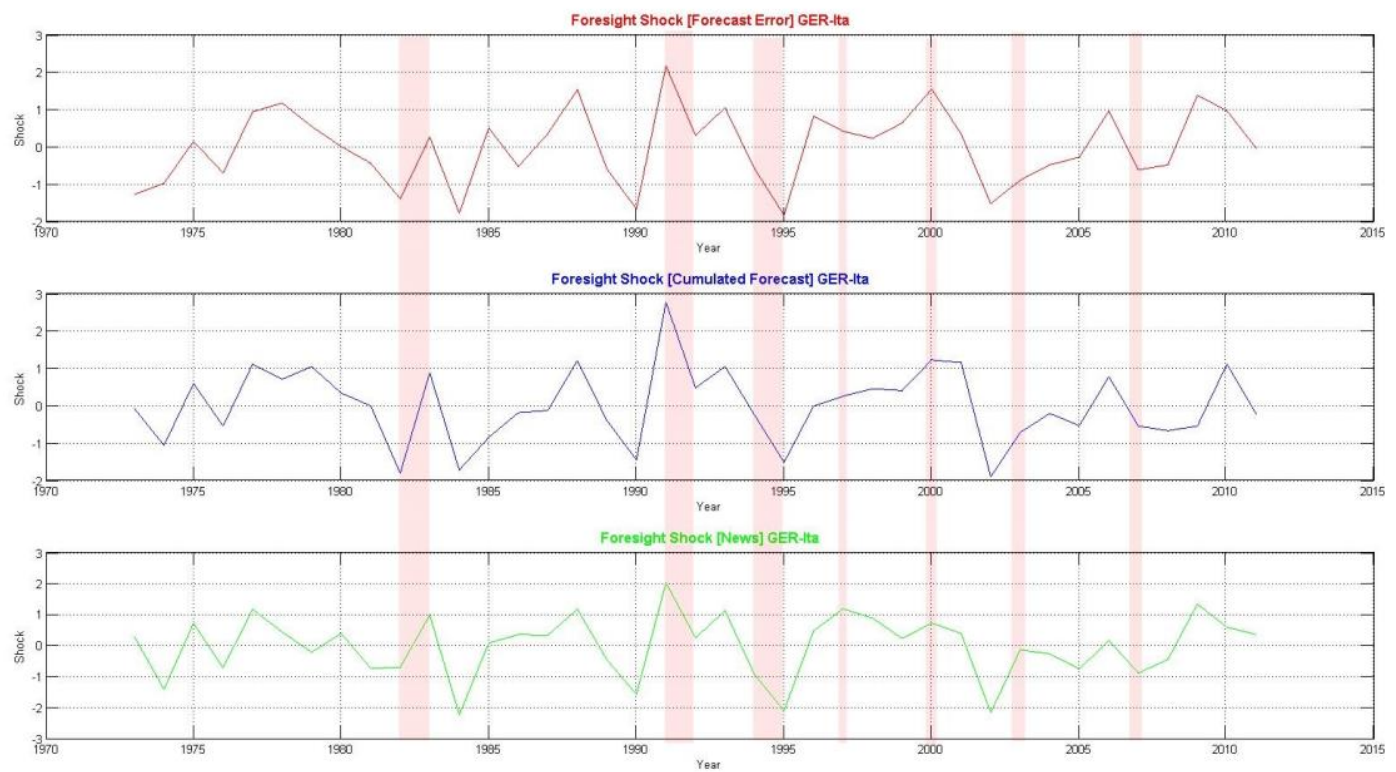

Figure 10: Foresight Shocks. Germany - Italy 

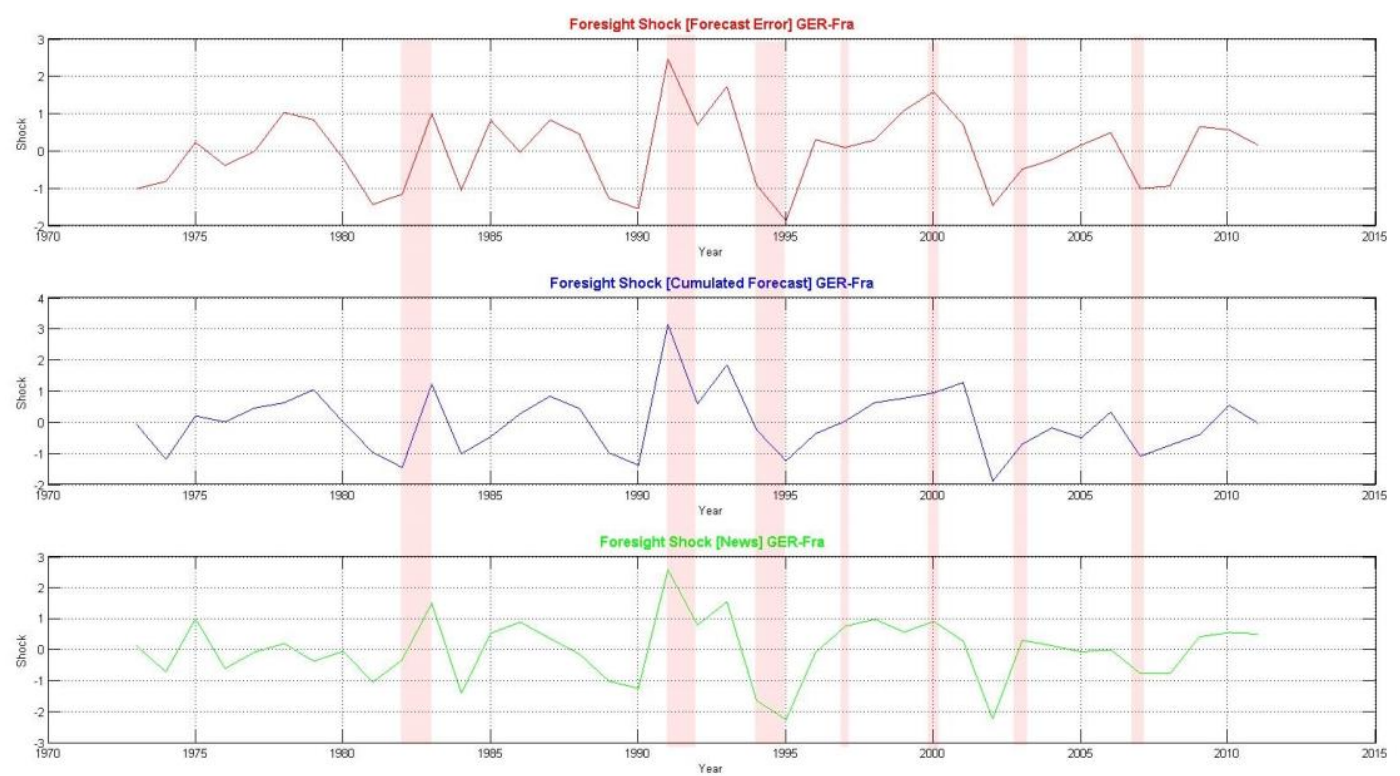

Figure 11: Foresight Shocks. Germany - France
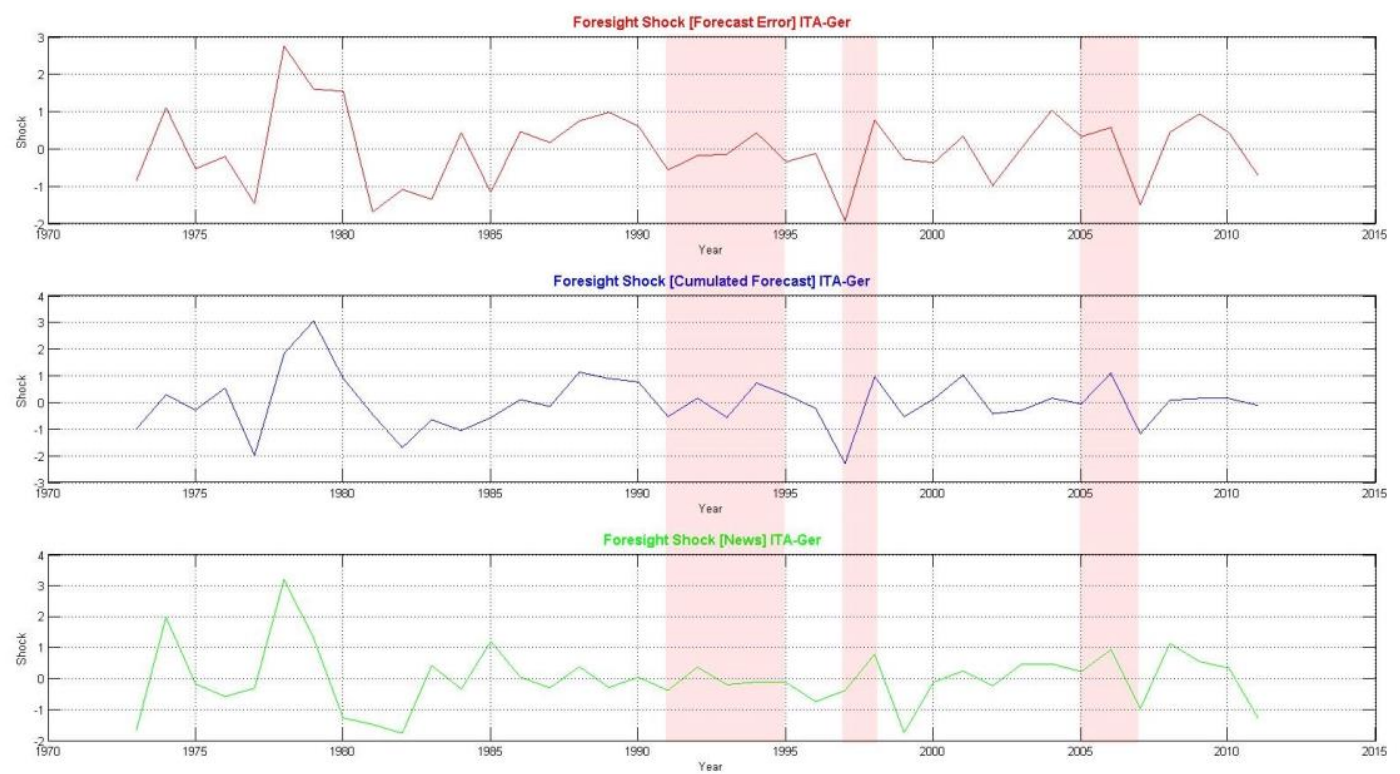

Figure 12: Foresight Shocks. Italy - Germany 

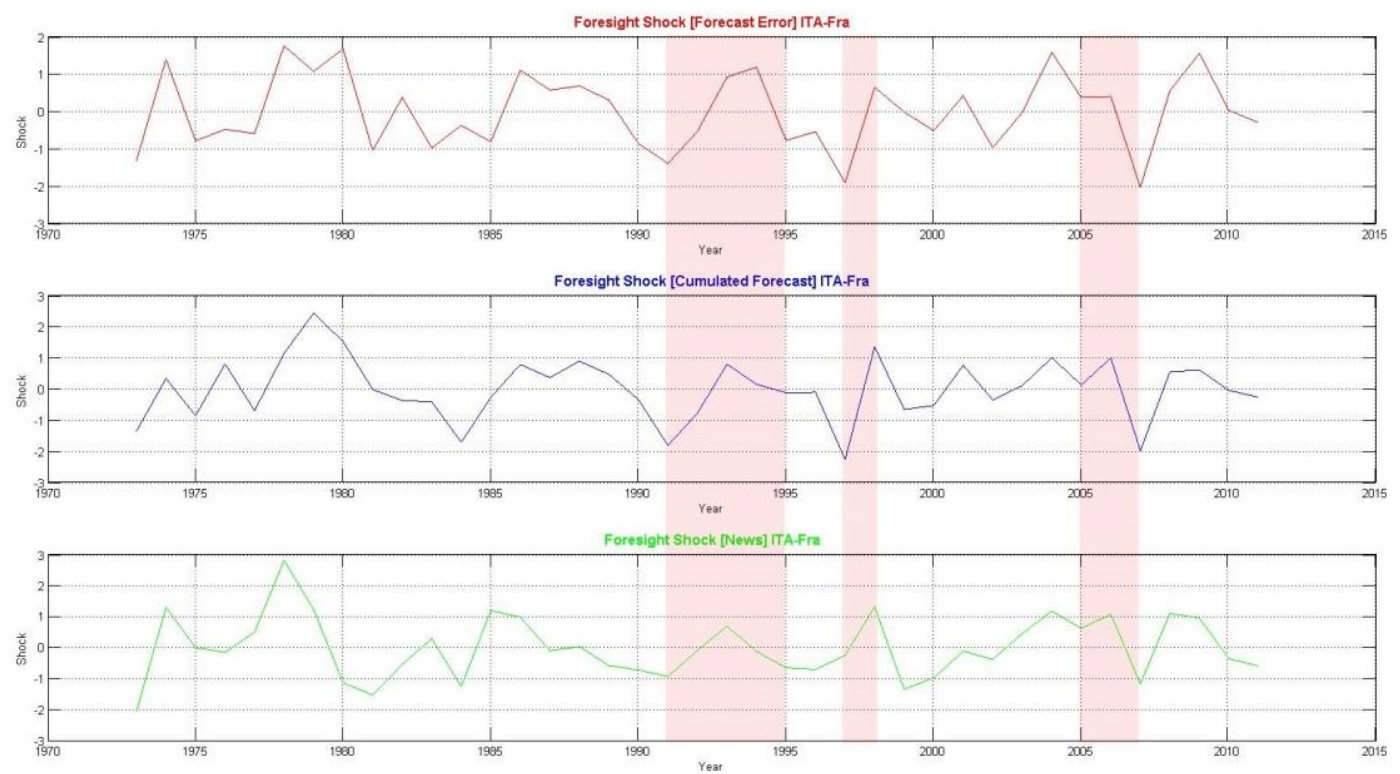

Figure 13: Foresight Shocks. Italy - France
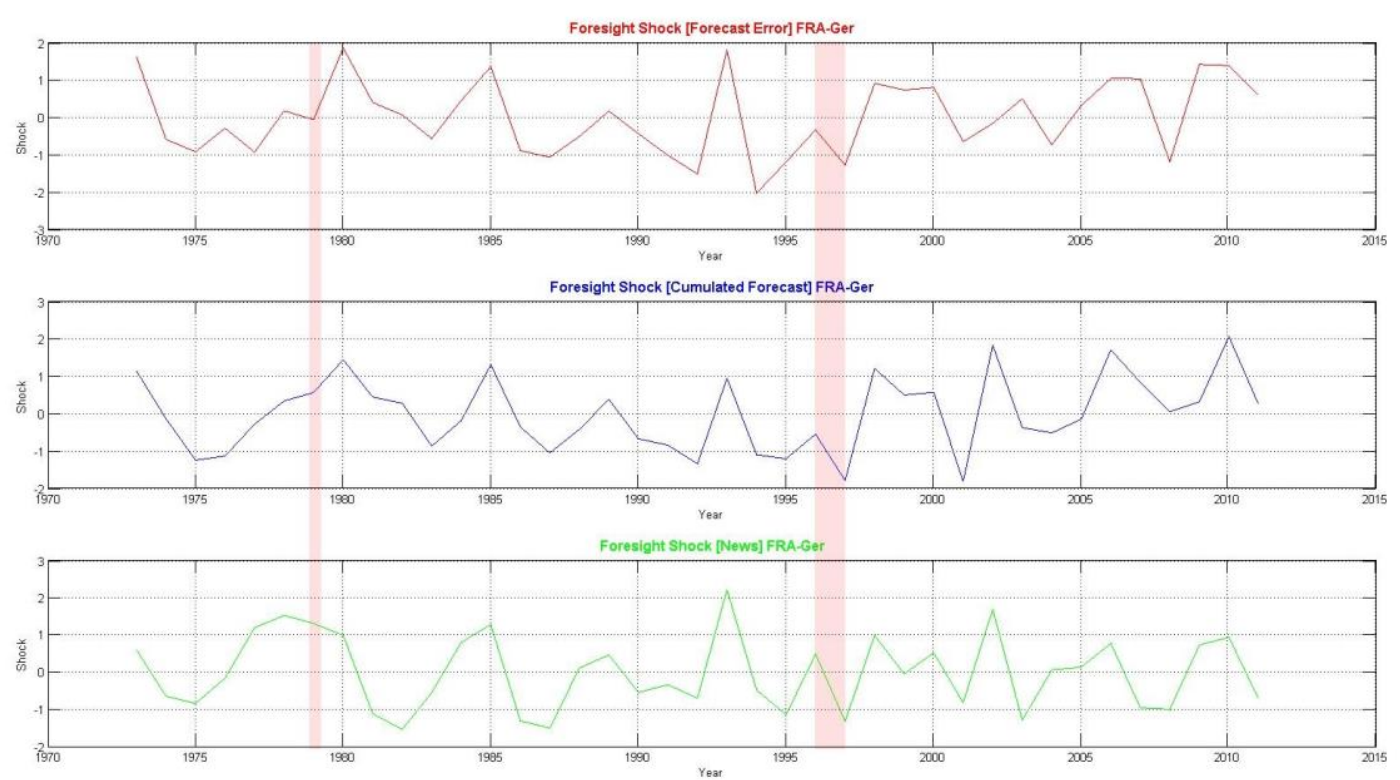

Figure 14: Foresight Shocks. France - Germany 
Issue no. $25 / 2018$
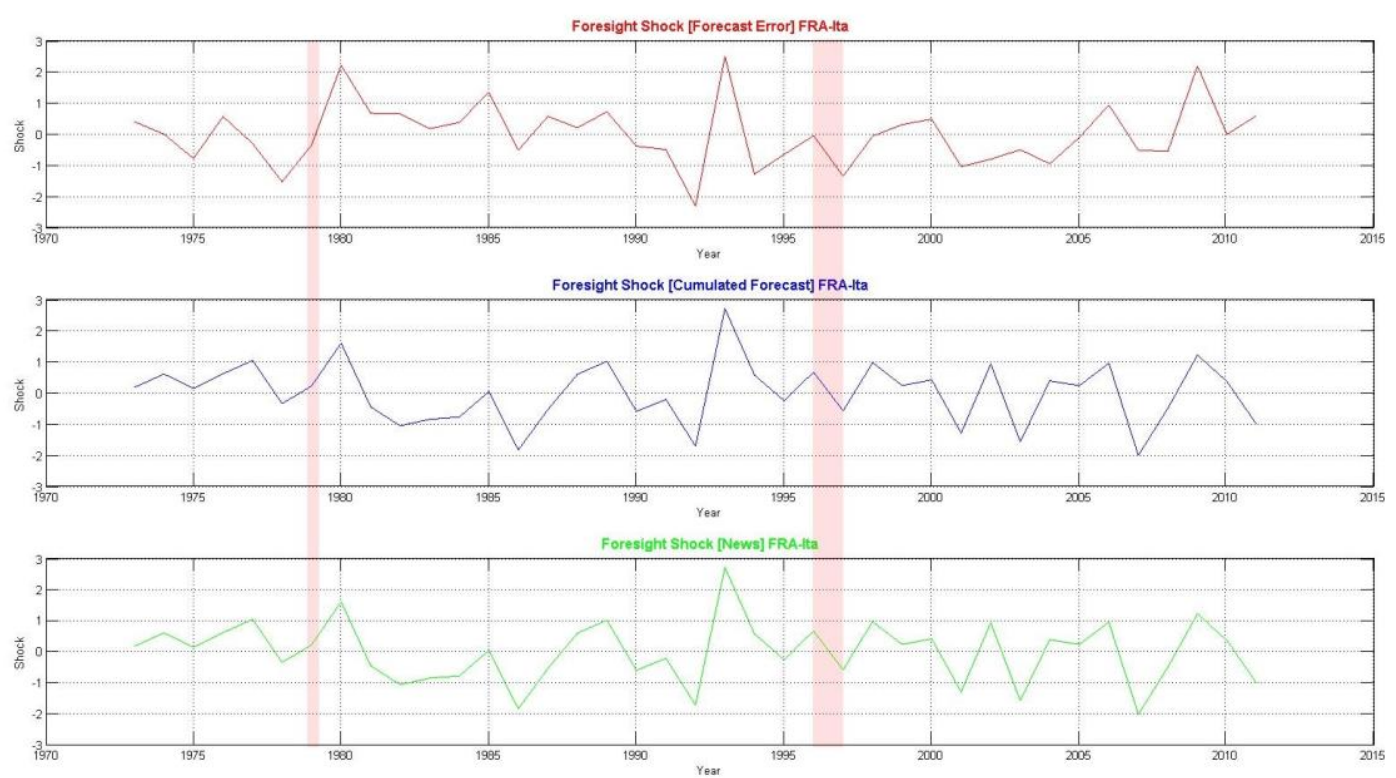

Figure 15: Foresight Shocks. France - Italy

All of the shocks are very similar. Despite capturing different aspects of the forecasting process, they all convey information related to changes in the government balance. They display negative spikes in correspondence to major episodes of fiscal retrenchment, as expected. In most of the cases, troughs are well before the start of consolidations, reflecting the extent of fiscal anticipation. Positive spikes occur immediately before or after consolidation episodes, capturing expectation rallies. A notable exception is the fiscal retrenchment of 1992-95 in Italy, where expectations are almost at. Overall, the evidence reinforces the results in Section 2 showing that the European Commission forecasts do provide useful information for fiscal foresight. 